\title{
Differential alteration of basaltic lava flows and hyaloclastites in Icelandic hydrothermal systems
}

\author{
Bruno M. J. Thien ${ }^{*}$, Georg Kosakowski and Dmitrii A. Kulik
}

\author{
* Correspondence: bruno.thien@psi.ch \\ Laboratory for Waste Management \\ (LES), Paul Scherrer Institut, 5232 \\ Villigen, Switzerland
}

\begin{abstract}
Geological field observations evidence that active and fossil Icelandic hydrothermal systems are typically embedded into an intercalation of almost completely altered and nearly unaltered volcanic rock layers. We investigated the reasons for this finding with help of geochemical reaction path calculations, by studying the mineralogical evolution of contrasting lithofacies-basalt flows and hyaloclastites at various temperatures and pressures, different recharge water composition, and gas content. From this study, we conclude that the initial porosity of protoliths and volume changes due to their transformation into secondary minerals are sufficient to explain the different extents of alteration as observed in field studies. In addition, we present a generalized kinetic model to estimate the alteration time of glassy fragments in hyaloclastite as a function of grain size, surface roughness, and temperature. This time was found to be rather short, ranging from a few hours to a few years.
\end{abstract}

Keywords: Hydrothermal alteration; Iceland; Lava flow; Hyaloclastite; Basalt; Basaltic glass; Secondary mineral; Porosity closure; Geochemical modeling

\section{Background}

\section{Motivation}

Icelandic hydrothermal systems have been extensively studied in the context of highenthalpy fluid circulation that allows efficient and cheap electrical power generation (e.g., Fridleifsson and Elders 2005). The aqueous alteration of basaltic rocks consumes $\mathrm{CO}_{2}$, therefore playing a role in the global carbon cycle (Dessert et al. 2003; Shibuya et al. 2013). This feature makes basaltic rocks as a good candidate for $\mathrm{CO}_{2}$ disposal (Matter et al. 2009; Gislason et al. 2010; Aradottir et al. 2012).

During the aqueous fluid circulation, the primary magmatic minerals or glass in the volcanic rocks (called "protolith" below) are generally in disequilibrium with the fluid because temperatures, pressures, and $\mathrm{H}_{2} \mathrm{O}$ fugacity are quite different from those during the volcanic rock formation. This leads to rock alteration that consists of the irreversible transformation of the protolith into a more stable phase assemblage of the (hydrated) secondary minerals, with possibly significant volume and porosity change. Over a given period of time, an increase of the porosity enhances the water circulation (if the pore space is connected, for example, via fractures), and therefore the extent of rock alteration. On the contrary, a decrease of the porosity would reduce the degree of alteration. A possible complete closure of porosity has been mentioned for systems 
prone to carbonate formation (Steefel and Lichtner 1998; Shao et al. 2013) and in natural and technical analogues on clay/cement interaction (Gaboreau et al. 2011; Pitty and Alexander 2014). In such a case, the fluid circulation may stop, preventing further rock alteration.

\section{Rock formations}

The subsurface stratigraphy of Iceland mainly consists in a succession of hyaloclastite formations and lava flows (Weisenberger and Selbekk 2009; Banik et al. 2014) sometimes intersected by basalt intrusions (Lonker et al. 1993; Mortensen et al. 2014). The thickness of individual layers is variable and irregular (Watton et al. 2013), varying between a few meters and a few hundred meters (Alfredsson et al. 2013).

Hyaloclastites consist of glassy fragments (at least 90 \% (Watton et al. 2013)) resulting from the fast cooling of lava due to the contact with water or ice (e.g., Watton et al. 2013). They are present in many volcanic systems all around the world (Zierenberg et al. 1995; Altaner et al. 2003; Honnorez 2003; Claridge and Campbell 2008; Moore et al. 2012; Barfod and Fitton 2014; Kanayama et al. 2014; Motelib et al. 2014) and also in Mars (Hovius et al. 2008; Scanlon et al. 2014). Hyaloclastites exhibit high porosity up to $60 \%$ (Franzson et al. 2010; Alfredsson et al. 2013); relatively high initial permeability from $10^{-13}$ to $10^{-12} \mathrm{~m}^{2}$ (Jarosch et al. 2008); and a wide range of granulometry: fine hyaloclastite (average grain diameter $<1 / 16 \mathrm{~mm}$ ), hyaloclastite sandstone $(1 / 16-$ $2 \mathrm{~mm}$ ), granular hyaloclastite $(2-4 \mathrm{~mm})$, and hyaloclastite breccia $(4-64 \mathrm{~mm}$ ) (Watton et al. 2013). Lava flows and basaltic intrusions mainly consist of dense crystalline basalts (Kristmannsdottir 1979) with primary porosity ranging from 5 to $40 \%$ (Franzson et al. 2008). Measured permeability generally varies between $1^{\circ} 10^{-15}$ and $1.5^{\circ} 10^{-13} \mathrm{~m}^{2}$ (Arnorsson 1995). Greatest permeabilities are vertical, due to faults and fractures. Hyaloclastites usually show more signs of hydrothermal alteration than basalt flows or intrusives (Wolff-Boenisch et al. 2006).

Kristmannsdottir (1979) classified Icelandic geothermal zones into two areas:

(1) High-temperature geothermal areas, within the zones of rifting and volcanism. Rocks are young (Quaternary), and are assumed to have not been altered previously at higher temperatures. Nevertheless, some authors evidenced temporary higher temperature conditions when magma was introduced into the geothermal reservoir, as in Krafla (Gudmundsson and Arnorsson 2005) and Reykjanes (Marks et al. 2010). A progressive hydrothermal mineral alteration sequence with increasing temperature and depth is generally observed (e.g., Marks et al. 2010). Above $200{ }^{\circ} \mathrm{C}$, the bulk of primary minerals or glass is generally completely altered (Franzson et al. 2008). The degree of alteration also depends on the structure of the rock. The more permeable and the less crystalline the protolith is, the more is the extent of its alteration. When compared at a similar temperature, hyaloclastites are usually completely altered, whereas intrusive and compact basalts appear rather fresh (Kristmannsdottir 1979; Lonker et al. 1993; Gudmundsson and Arnorsson 2002; Gudmundsson and Arnorsson 2005; Marks et al. 2010). For instance, in Hvalfjördur area, secondary minerals mainly occur in the top and bottom parts of basaltic flow units (Weisenberger and Selbekk 2009).

(2) Low-temperature geothermal areas, in the older Quaternary and Tertiary rock formations, in which rocks may have experienced previous low-grade metamorphic 
events. In low-temperature areas, the extent of protolith alteration ranges from 0 to 60 \% (Schopka et al. 2006; Alfredsson et al. 2013). The massive observation of zeolites in Tertiary areas is in contradiction with the mineralogy observed in high temperature areas. This had been explained by a progressive low-grade metamorphism due to the burial of lava succession and higher heat flow caused by the influence of central volcano (Neuhoff et al. 1999; Weisenberger and Selbekk 2009). In those areas, altered hyaloclastites exhibit a wide range of permeability, from $1^{\circ} 10^{-17}$ and $1.5^{\circ} 10^{-11} \mathrm{~m}^{2}$, positively correlated to the porosity (Frolova et al. 2005). The lowest permeabilities correspond to oldest hyaloclastites (2-2.5 m.y.) which experienced low-grade metamorphism.

The secondary mineral-fluid equilibrium is closely approached at temperatures above $150{ }^{\circ} \mathrm{C}$ (Gudmundsson and Arnorsson 2005) or even sometimes already at $100{ }^{\circ} \mathrm{C}$ (Scott et al. 2014). Nevertheless, Lonker et al. (1993) identified some departures from equilibrium above $200{ }^{\circ} \mathrm{C}$, which he attributed to some kinetic effects. Secondary minerals were found in vesicles and fractures, as well as in the rock matrix as replacement of protolith (Lonker et al. 1993). The presence of secondary minerals that do not match with the actual reservoir temperature can be explained by prior heating episodes (Lonker et al. 1993; Arnorsson 1995; Marks et al. 2010). These earlier events could have been caused not only by magma intrusions but also by hydrostatic pressure increase due to the progressive burial of lava succession or the ice load during Pleistocene. The occurrence of wollastonite in Krafla (Gudmundsson and Arnorsson 2005), garnet in Krafla and Namafjall (Gudmundsson and Arnorsson 2005), or some zeolites in Hvalfjördur (Weisenberger and Selbekk 2009) are assumed to be the result of contact metamorphism rather than of purely hydrothermal alteration.

Secondary minerals precipitated in Icelandic basaltic hydrothermal systems had been described in many studies (Table 1). In this table, only minerals are listed that were positively identified. For instance, smectites, when only identified as "smectites", are not reported in this table because smectite is not a single mineral, but a mineral family which includes montmorillonites, nontronites, beidellites, saponites, and hectorites. Thermodynamic properties of them can be very different from one category to another one (Vieillard 2000). There is a lack of accurate smectite identification. Actually, very accurate XRD patterns are necessary to differentiate a trioctahedral smectite from a dioctahedral smectite (Thien et al. 2010); this task is non-trivial if the sample contains some amorphous material (e.g., glass, amorphous silica). Some authors actually represented observed mineralogical assemblages as a function of depth (pressure) and/or temperature (Arnorsson 1995; Gudmundsson and Arnorsson 2005; Lonker et al. 1993; Marks et al. 2010). The consistency between those different profiles is not perfect, which can be explained by different recharge water composition, geological heterogeneities, or previous thermal events. Overall, synthesis of the available information suggests a classification of Icelandic geothermal systems into three zones:

- First zone is up to $100{ }^{\circ} \mathrm{C}$ (from the surface to 300-m depth) which contains smectites, calcite, low-temperature zeolites, and numerous sulfides, oxides, and hydroxides. Quartz is generally not present; chalcedony, a polymorph of $\mathrm{SiO}_{2}$, is typically observed; 
Table 1 Secondary minerals identified in basaltic systems with hydrothermal alteration

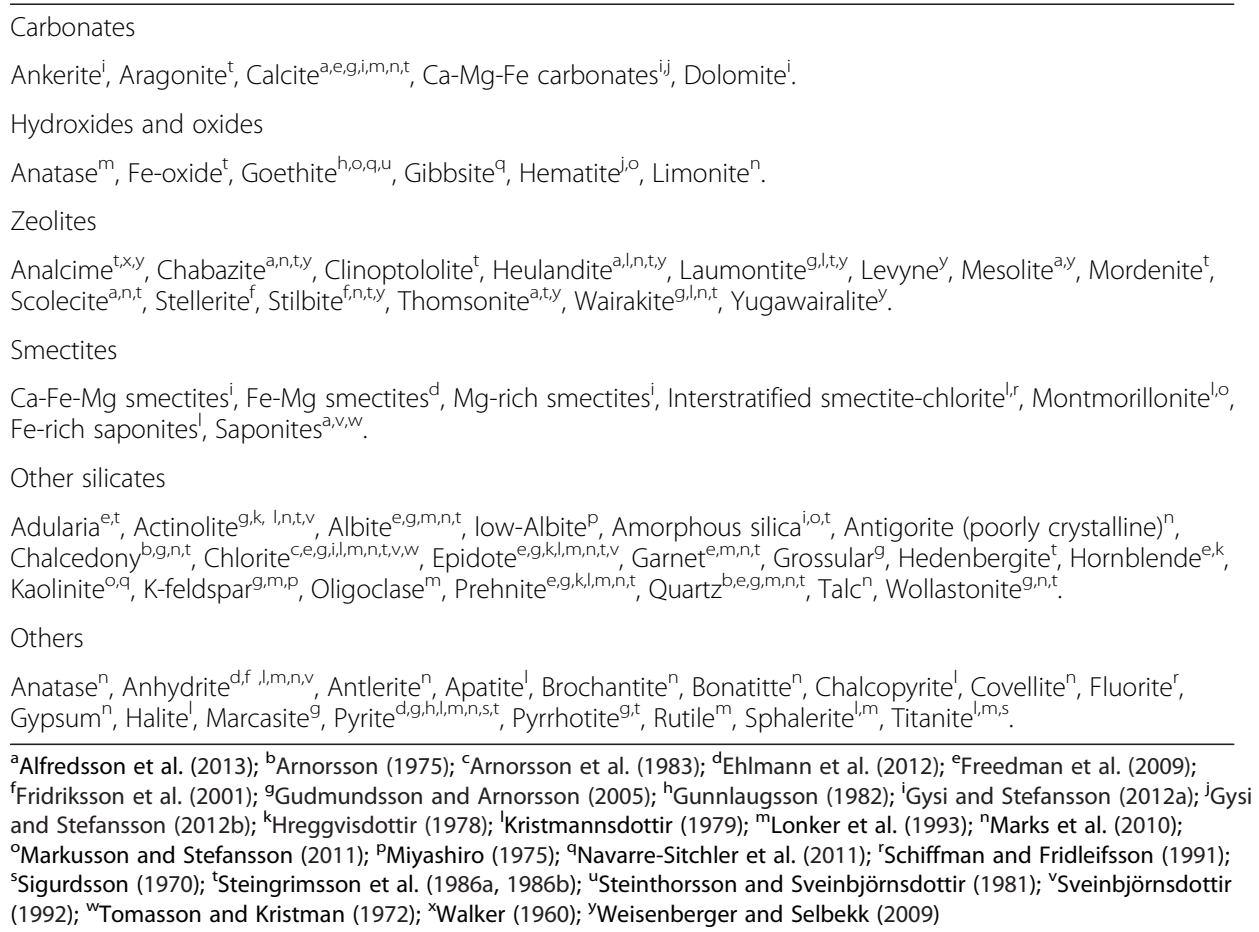

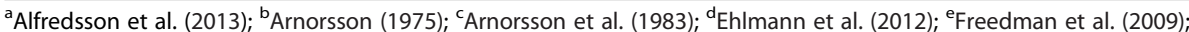
${ }^{f}$ Fridriksson et al. (2001); ${ }^{9}$ Gudmundsson and Arnorsson (2005); ${ }^{\text {h} G u n n l a u g s s o n ~(1982) ; ~}{ }^{1}$ Gysi and Stefansson (2012a); ${ }^{j} G y s i$ and Stefansson (2012b); ${ }^{\mathrm{K}}$ Hreggvisdottir (1978); 'Kristmannsdottir (1979); ${ }^{\mathrm{m}}$ Lonker et al. (1993); ${ }^{\mathrm{n}}$ Marks et al. (2010);

${ }^{\circ}$ Markusson and Stefansson (2011); ${ }^{\text {P} M i y a s h i r o ~(1975) ; ~}{ }^{\text {}}$ Navarre-Sitchler et al. (2011); 'Schiffman and Fridleifsson (1991);

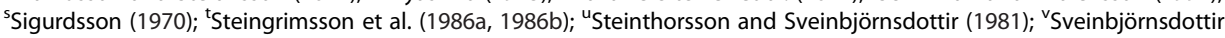
(1992); 'Tomasson and Kristman (1972); ${ }^{x}$ Walker (1960); ${ }^{y}$ Weisenberger and Selbekk (2009)

- second zone is from 100 to $200{ }^{\circ} \mathrm{C}$ (from $300 \mathrm{~m}$ to $500-1000 \mathrm{~m}$ ) containing mixed-layer smectites, other zeolites (wairakite and laumontite), calcite, chalcedony, various sulfides like pyrite;

- third zone is above $200{ }^{\circ} \mathrm{C}$ which contains chlorite, quartz, albite, wollastonite, prehnite, and epidote. At highest temperature/largest depths, amphiboles (actinolite and hornblende) and garnet were observed.

It is worth to mention that the first zone can be subject to atmospheric oxidation (Marks et al. 2010), whereas the deep zones are typically anoxic.

Tectonic spreading movements pull rock formations away on either side of magmatic activity areas. It results in fossil geothermal systems, commonly found in Quaternary and Tertiary formations in Iceland (Arnorsson 1975). This implies that active highenthalpy geothermal systems are relatively young. This study is mainly focused on high-enthalpy geothermal areas.

\section{Fluid circulation}

Recharge water in central-Icelandic hydrothermal systems is mainly meteoric water because it can easily penetrate highly permeable volcanic rocks (Arnorsson 1995; Marks et al. 2010). In Reykjanes and Svartsengi areas, recharge water mainly consists of seawater (Kristmannsdottir 1979). During the Pleistocene, the recharge water in Reykjanes was meteoric (Marks et al. 2010). Arnorsson (1995) estimated with the available permeability data that the age of geothermal waters emerging in wells was no more than a few tens of years, and a few hundreds of years in areas having the lowest permeability. 
Fluid analyses from boreholes indicate the presence of gases (e.g., Stefansson and Arnorsson 2002; Kaasalainen and Stefansson 2011). The source of gas is not very well established but is commonly associated with young magma intrusions (Arnorsson 1995; Gudmundsson and Arnorsson 2002). When a depressurization boiling occurs, the vapor phase is produced, and volatiles like $\mathrm{CO}_{2}, \mathrm{H}_{2} \mathrm{~S}$, and $\mathrm{H}_{2}$ preferentially enter this phase. Vapor fraction, when exists, does not exceed $0.2 \%$ by mass of the total fluid (Gudmundsson and Arnorsson 2002; Scott et al. 2014). Cross-checking of fluid analysis from different borehole analyses (Arnorsson 1995; Gudmundsson and Arnorsson 2002; Markusson and Stefansson 2011; Scott et al. 2014) allows establishing a range of possible aqueous $\mathrm{CO}_{2}$ and $\mathrm{H}_{2} \mathrm{~S}$ concentrations in Icelandic geothermal systems: 0.0003-0.35 $\mathrm{M}$ for $\mathrm{CO}_{2} ; 0.0001-0.05 \mathrm{M}$ for $\mathrm{H}_{2} \mathrm{~S}$. It is difficult to estimate those values and to compare them with each other, because concentrations in both liquid and gas depends on temperature separation upon sampling (Gudmundsson and Arnorsson 2002). Because the most important part of the system consists in non-boiling zone (i.e., no steam), we recalculated the $\mathrm{H}_{2} \mathrm{~S}$ and $\mathrm{CO}_{2}$ concentrations considering liquid analysis, gas analysis, and average proportion of gas in the fluid.

In those studies, the measured $\mathrm{pH}$ of water is weakly alkaline (i.e., 8-9) and drops to sub-neutral (i.e., 5-6) when corrected according to the temperature increase with depth. Close to the surface, the gas phase due to depressurization boiling mixes with surface water which contains atmospheric oxygen (Markusson and Stefansson 2011), oxidizing $\mathrm{H}_{2} \mathrm{~S}$ to $\mathrm{SO}_{4}^{2-}$. This results in a strong drop of $\mathrm{pH}$ (i.e., 2-3), which triggers the acidic leaching of near-surface zones.

\section{Relation between porosity and permeability}

Porosity and permeability are two essential factors that drive the evolution of the hydrothermal system. The porosity and its connectivity define the permeability and the amount of mineral surface accessible to the reaction with water.

In Icelandic reservoir rocks, the permeability generally increases with the porosity (e.g., Franzson et al. 2001). Such a correlation was measured for hyaloclastites (Frolova et al. 2005; Franzson et al. 2011), as well as for basalts (Sigurdsson and Stefansson 2002; Saar and Manga 1999). There are some exceptions. For instance, Franzson et al. (2001) reported a specific case of a young fresh olivine tholeiite lava flow, in which the permeability decreases with the porosity.

In hyaloclastites, macropores can be filled out with secondary minerals when secondary microporosity is formed (Franzson et al. 2010). The correlation between porosity and permeability is being influenced by the evolution of the pore space. It was reported that the connectivity of the pore space (which strongly influenced the permeability) is changing during the rock alteration (Navarre-Sitchler et al. 2011; Navarre-Sitchler et al. 2013).

In this study, we calculated volume changes of mineral phases, which were transformed into a porosity value. The models give no information on connectivity or change in pore size/pore shape. It implies a correlation between porosity and permeability for a specific rock type. We can postulate that permeability changes result from changes in porosity.

\section{The need for modeling}

Most mineralogical field observations in basaltic hydrothermal systems, given in the literature and summarized in this paper, remain qualitative. There is a real lack of the 
quantitative mineralogical data. Consequently, the modeling approaches of rock alteration in those systems cannot be fully validated.

To a wider extent, numerous modeling studies of the mineralogical evolution of basaltic systems have been done (Griffith and Shock 1997; Franzson et al. 2008; Navarre-Sitchler et al. 2011; Gysi and Stefansson 2011; Pham et al. 2011; Aradottir et al. 2012; Aradottir et al. 2013; Catalano 2013; Hellevang et al. 2013), but none of those reported the porosity evolution during reactive transport and water-rock interaction. The evolution of porosity has potentially important implications for basalt alteration. Actually, in low-porosity rocks, changes in porosity noticeably modify effective diffusivity and permeability (Navarre-Sitchler et al. 2009). Modeling the evolution of porosity is a difficult task that requires knowing the value of the initial connected porosity and how it changes during the reaction. Some studies evidenced that the initial porosity decreases during the alteration of basaltic formations (Neuhoff et al. 1999; Gustavson 2006), but also the contrary (Navarre-Sitchler et al. 2013).

In this study, the mineral volume evolution during basaltic rock hydrothermal alteration was simulated using a sequential reactors model. The sensitivity of different parameters was tested (initial protolith porosity, temperature and pressure, gas content, pore geometry) in order to assess what factors influence most the hydrothermal rock alteration in Icelandic hydrothermal systems.

\section{Methods}

\section{Geochemical model setup}

Mineralogical assemblages were modeled using the GEM-Selektor v.3 geochemical modeling package (Kulik et al. 2013; Wagner et al. 2012). We considered the equilibrium dissolution of a primary basaltic rock and a primary basaltic glass at various pressures and temperatures, and various initial water compositions (i.e., freshwater and seawater), with and without volcanic gas $\left(\mathrm{H}_{2} \mathrm{~S}\right.$ and $\left.\mathrm{CO}_{2}\right)$.

The mineralogical composition of basalt was calculated using a chemical composition given by Markusson and Stefansson (2011) (Table 2). The glass composition is given by Gysi and Stefansson (2011), see Table 3. In order to simplify the system, minor elements $\mathrm{K}, \mathrm{Mn}, \mathrm{Ti}, \mathrm{P}$, and $\mathrm{Zr}$ were not considered. The mole amounts of basalt and glass were adjusted in order to reach the desired porosity per $1 \mathrm{dm}^{3}$ of water. The composition of the water is indicated in Table 4. For modeling the impact of volcanic gases, $0.3 \mathrm{M}$ of $\mathrm{CO}_{2}$ and $0.2 \mathrm{M}$ of $\mathrm{H}_{2} \mathrm{~S}$ were added to the system composition. Those gas

Table 2 Mineralogical composition of fresh basalt, calculated using the chemical composition given by Markusson and Stefansson (2011). Molar mass $=228.63 \mathrm{~g} / \mathrm{mol}$ and density $=3.1 \mathrm{~g} / \mathrm{cm}^{3}$

\begin{tabular}{llll}
\hline Mineral & Formula & $\mathrm{M}$ & $\% \mathrm{~mol}$ \\
\hline Albite & $\mathrm{NaAlSi}_{3} \mathrm{O}_{8}$ & 262.223 & 0.16 \\
Anorthite & $\mathrm{CaAl}_{2} \mathrm{Si}_{2} \mathrm{O}_{8}$ & 277.41 & 0.24 \\
Diopside & $\mathrm{CaMgSi}_{2} \mathrm{O}_{6}$ & 216.55 & 0.25 \\
Enstatite & $\mathrm{Mg}_{2} \mathrm{Si}_{2} \mathrm{O}_{6}$ & 200.7774 & 0.08 \\
Forsterite & $\mathrm{Mg}_{2} \mathrm{SiO}_{4}$ & 140.6931 & 0.09 \\
Fayalite & $\mathrm{Fe}_{2} \mathrm{SiO}_{4}$ & 203.773 & 0.16 \\
Magnetite & $\mathrm{Fe}_{3} \mathrm{O}_{4}$ & 231.54 & 0.02 \\
\hline
\end{tabular}


Table 3 Chemical composition of fresh basaltic glass, per 1 mol Si, derived from Gysi and Stefansson (2011)

\begin{tabular}{ll}
\hline Component & Mol amount \\
\hline $\mathrm{Al}_{2} \mathrm{O}_{3}$ & 0.350 \\
$\mathrm{CaO}$ & 0.270 \\
$\mathrm{FeO}$ & 0.169 \\
$\mathrm{Fe}_{2} \mathrm{O}_{3}$ & 0.012 \\
$\mathrm{MgO}$ & 0.260 \\
$\mathrm{Na}_{2} \mathrm{O}$ & 0.080 \\
$\mathrm{SiO}_{2}$ & 1.000 \\
\hline
\end{tabular}

Molar mass $=119.13 \mathrm{~g} / \mathrm{mol}$ and density $=2.9 \mathrm{~g} / \mathrm{cm}^{3}$

quantities allow to reproduce average $\mathrm{H}_{2} \mathrm{~S}$ and $\mathrm{CO}_{2}$ aqueous concentrations and $\mathrm{pH}$ measured by Stefansson et al. (2011) in a similar system $\left(250{ }^{\circ} \mathrm{C}\right.$, seawater-like fluid).

A realistic model suitable for various hydrothermal systems should account for every mineral mentioned in Table 1. Nevertheless, in order to reduce the complexity of the chemical system, and in accordance with basalt and basaltic glass compositions in Tables 2 and 3, respectively, we did not consider accessory minerals containing the trace elements $\mathrm{K}, \mathrm{Mn}, \mathrm{F}, \mathrm{P}, \mathrm{Cu}, \mathrm{Ti}$, and $\mathrm{Zr}$, assuming that their absence or presence is not expected to trigger relevant changes to the system. These elements can be incorporated in major minerals (e.g., Curti 1999) or precipitate as accessory minerals (Kaasalainen and Stefansson 2012). In both cases, their amount is expected to be too small to noticeably affect the mineral volume of the system. In addition, the amount of trace elements varies as a function of the location of the field (Kaasalainen and Stefansson 2012). In this study, we wanted to present a general view of Icelandic hydrothermal system, rather than to consider a very specific case. Minerals which led to inconsistent phase assemblages were removed from the chemical system definition; it is the case of goethite for instance, which is actually considered as a metastable phase (Berner 2013). Selected minerals with their thermodynamic parameters are listed in Table 5.

Table 4 Stoichiometry of sea salt used for setting up initial water compositions, taken from the tutorial of GEM-Selektor v.3

\begin{tabular}{ll}
\hline Element & Mol amount \\
\hline $\mathrm{C}$ & 0.00187109 \\
$\mathrm{Ca}$ & 0.010264347 \\
$\mathrm{Cl}$ & 0.54570368 \\
$\mathrm{H}$ & 0.002257133 \\
$\mathrm{~K}$ & 0.010187321 \\
$\mathrm{Mg}$ & 0.053026052 \\
$\mathrm{Na}$ & 0.46738417 \\
$\mathrm{O}$ & 0.1193977 \\
$\mathrm{~S}$ & 0.028173998 \\
$\mathrm{Si}$ & 0.000153078 \\
\hline
\end{tabular}

To create the seawater-like solution, we mixed $1000 \mathrm{~g}$ of water with $35 \mathrm{~g}$ of this stoichiometry. To create the fresh water solution, we mixed $1000 \mathrm{~g}$ of water with $0.035 \mathrm{~g}$ of this stoichiometry, and $3^{\circ} 10^{-5} \mathrm{~mol}$ of $\mathrm{CO}_{2} \cdot 1^{\circ} 10^{-6} \mathrm{~mol}$ of $\mathrm{O}_{2}$ was added in order to insure stability within phase calculations 
Table 5 Selected minerals and their thermodynamic data

\begin{tabular}{|c|c|c|c|c|c|c|c|c|}
\hline Mineral & Formula & $\Delta \mathrm{G}_{\mathrm{f}}^{\circ}(\mathrm{J} / \mathrm{mol})$ & $S^{\circ}(\mathrm{J} / \mathrm{mol} / \mathrm{K})$ & $a(\mathrm{~J} / \mathrm{mol} / \mathrm{K})$ & $b(\mathrm{~J} / \mathrm{mol} / \mathrm{K})$ & $\mathrm{c}(\mathrm{J} / \mathrm{mol} / \mathrm{K})$ & $V^{\circ}(\mathrm{J} / \mathrm{bar})$ & Reference \\
\hline Albite & $\mathrm{Na}\left(\mathrm{AlSi}_{3}\right) \mathrm{O}_{8}$ & -3708313 & 207.15 & 342.59 & 0.0149 & $-2.10 \mathrm{E}+07$ & 10.025 & 598 \\
\hline Low-albite & $\mathrm{Na}\left(\mathrm{AlSi}_{3}\right) \mathrm{O}_{8}$ & -3708313 & 207.15 & 258.15 & 0.0582 & $-6.28 \mathrm{E}+06$ & 10.007 & 598 \\
\hline Analcime & $\mathrm{NaAlSi}_{2} \mathrm{O}_{6}\left(\mathrm{H}_{2} \mathrm{O}\right)$ & -3078890 & 231.97 & 132.50 & 0.2555 & $-2.13 E-05$ & 9.710 & Neuhoff (2000) \\
\hline Anhydrite & $\mathrm{CaSO}_{4}$ & -1321830 & 106.69 & 70.21 & 0.0987 & $0.00 E+00$ & 4.594 & 598 \\
\hline Anorthite & $\mathrm{Ca}\left(\mathrm{Al}_{2} \mathrm{Si}_{2}\right) \mathrm{O}_{8}$ & -3991862 & 205.43 & 264.89 & 0.0619 & $-6.46 E+06$ & 10.079 & 598 \\
\hline Boehmite & $\mathrm{AlO}(\mathrm{OH})$ & -908974 & 48.45 & 60.40 & 0.0176 & $0.00 \mathrm{E}+00$ & 1.954 & 598 \\
\hline Calcite & $\mathrm{CaCO}_{3}$ & -1128810 & 92.50 & 104.90 & 0.0050 & $-9.51 E-05$ & 3.693 & Holland and Powell (1998) \\
\hline Ca-chabazite & $\mathrm{Ca}\left(\mathrm{Al}_{2} \mathrm{Si}_{4}\right) \mathrm{O}_{12}\left(\mathrm{H}_{2} \mathrm{O}\right)_{6}$ & -7156380 & 584.23 & 564.18 & 0.9033 & $-1.59 E+02$ & 24.745 & Neuhoff (2000) \\
\hline Na-chabazite & $\mathrm{Na}_{2}\left(\mathrm{Al}_{2} \mathrm{Si}_{4}\right) \mathrm{O}_{12}\left(\mathrm{H}_{2} \mathrm{O}\right)_{6}$ & -7115170 & 619.51 & 591.72 & 0.9192 & $-1.59 E+02$ & 24.745 & Neuhoff (2000) \\
\hline Chalcedony & $\mathrm{SiO}_{2}$ & -854691 & 41.34 & 46.94 & 0.0343 & $-1.13 E+06$ & 2.269 & $\$ 98$ \\
\hline Clinochlore-14A & $\mathrm{Mg}_{5} \mathrm{Al}\left(\mathrm{AlSi}_{3}\right) \mathrm{O}_{10}(\mathrm{OH})_{8}$ & -8263350 & 410.50 & 1161.80 & 0.0101 & $-7.66 \mathrm{E}-04$ & 20.710 & Holland and Powell (1998) \\
\hline Daphnite-14A & $\left.\mathrm{Fe}_{5} \mathrm{Al}(\mathrm{AlSi})_{3}\right)_{10}(\mathrm{OH})_{8}$ & -6535560 & 545.00 & 1237.40 & 0.0014 & $-3.74 E-04$ & 21.342 & Holland and Powell (1998) \\
\hline Diaspore & $\mathrm{AlO}(\mathrm{OH})$ & -913794 & 35.27 & 60.40 & 0.0176 & $0.00 E+00$ & 1.776 & 598 \\
\hline Diospside & $\mathrm{CaMg}\left(\mathrm{SiO}_{3}\right)_{2}$ & -3028296 & 143.09 & 221.21 & 0.0328 & $-6.59 E+06$ & 6.609 & 598 \\
\hline Dolomite & $\mathrm{CaMg}\left(\mathrm{CO}_{3}\right)_{2}$ & -2161510 & 156.00 & 305.89 & -0.0049 & $0.00 E+00$ & 6.439 & Holland and Powell (1998) \\
\hline Enstatite & $\mathrm{MgSiO}_{3}$ & -1459923 & 67.78 & 102.72 & 0.0198 & $-2.63 E+06$ & 3.128 & 598 \\
\hline Epidote & $\mathrm{Ca}_{2} \mathrm{Fe}|3| \mathrm{Al}_{2} \mathrm{Si}_{3} \mathrm{O}_{12}(\mathrm{OH})$ & -6070591 & 314.97 & 492.13 & 0.0536 & $-1.33 \mathrm{E}+07$ & 13.920 & 598 \\
\hline Fayalite & $\mathrm{Fe}_{2} \mathrm{SiO}_{4}$ & -1381695 & 148.32 & 152.76 & 0.0392 & $-2.80 E+06$ & 4.639 & 598 \\
\hline Ferrous oxide & $\mathrm{FeO}$ & -251446 & 60.75 & 50.72 & 0.0087 & $-3.14 \mathrm{E}+05$ & 1.200 & S98 \\
\hline Forsterite & $\mathrm{Mg}_{2} \mathrm{SiO}_{4}$ & -2056704 & 95.19 & 149.83 & 0.0274 & $-3.56 E+06$ & 4.379 & 598 \\
\hline Gibbsite & $\mathrm{Al}(\mathrm{OH})_{3}$ & -1155487 & 70.08 & 36.19 & 0.1908 & $0.00 E+00$ & 3.196 & 598 \\
\hline Grossular & $\mathrm{Ca}_{3} \mathrm{Al}_{2} \mathrm{Si}_{3} \mathrm{O}_{12}$ & -6260549 & 254.68 & 435.21 & 0.0712 & $-1.14 \mathrm{E}+07$ & 12.530 & 598 \\
\hline Gypsum & $\mathrm{CaSO}_{4}\left(\mathrm{H}_{2} \mathrm{O}\right)_{2}$ & -1797763 & 193.80 & 91.38 & 0.3180 & $0.00 E+00$ & 7.469 & 598 \\
\hline Halite & $\mathrm{NaCl}$ & -384120 & 72.13 & 45.94 & 0.0163 & $0.00 E+00$ & 2.702 & $\$ 98$ \\
\hline Hedenbergite & $\mathrm{CaFe}\left(\mathrm{SiO}_{3}\right)_{2}$ & -2673568 & 170.29 & 229.33 & 0.0342 & $-6.28 E+06$ & 6.827 & 598 \\
\hline
\end{tabular}


Table 5 Selected minerals and their thermodynamic data (Continued)

\begin{tabular}{|c|c|c|c|c|c|c|c|c|}
\hline Ca-heulandite & $\mathrm{Ca}\left(\mathrm{Al}_{2} \mathrm{Si}_{7}\right) \mathrm{O}_{18}\left(\mathrm{H}_{2} \mathrm{O}\right)_{6}$ & $-9,726,320$ & 732.67 & 742.54 & 0.0632 & $-1.43 E-03$ & 31.927 & Neuhoff (2000) \\
\hline Na-heulandite & $\mathrm{Na}_{2}\left(\mathrm{Al}_{2} \mathrm{Si}_{7}\right) \mathrm{O}_{18}\left(\mathrm{H}_{2} \mathrm{O}\right)_{6}$ & -9371886 & 736.39 & 722.37 & 0.0631 & $-1.40 E-03$ & 31.943 & Neuhoff (2000) \\
\hline Hydromagnesite & $\mathrm{Mg}_{5}(\mathrm{OH})_{2}\left(\mathrm{CO}_{3}\right)_{4}\left(\mathrm{H}_{2} \mathrm{O}\right)_{4}$ & -5864658 & 541.33 & 591.87 & 0.2731 & $-9.07 E+06$ & 20.880 & S98 \\
\hline K-feldspar & $\mathrm{K}\left(\mathrm{AlSi}_{3}\right) \mathrm{O}_{8}$ & -3746245 & 213.93 & 320.57 & 0.0180 & $-1.25 \mathrm{E}+07$ & 10.887 & 598 \\
\hline Kaolinite & $\mathrm{Al}_{2} \mathrm{Si}_{2} \mathrm{O}_{5}(\mathrm{OH})_{4}$ & -3801720 & 203.70 & 436.70 & -0.0034 & $-4.06 \mathrm{E}-05$ & 9.952 & Holland and Powell (1998) \\
\hline Laumontite & $\mathrm{Ca}\left(\mathrm{Al}_{2} \mathrm{Si}_{4}\right) \mathrm{O}_{12}\left(\mathrm{H}_{2} \mathrm{O}\right)_{4.5}$ & -6800520 & 483.91 & 582.22 & 0.1448 & $-8.99 E-04$ & 20.755 & Neuhoff (2000) \\
\hline Magnesite & $\mathrm{MgCO}_{3}$ & -1027740 & 65.10 & 186.40 & 0.0000 & $0.00 E+00$ & 2.802 & Holland and Powell (1998) \\
\hline Magnetite & $\mathrm{FeFe}|3|_{2} \mathrm{O}_{4}$ & -1014930 & 145.73 & 91.55 & 0.2017 & $0.00 E+00$ & 4.452 & 598 \\
\hline Marcassite & $\mathrm{FeS}|0| \mathrm{S}|-2|$ & -153335 & 36.82 & 74.81 & 0.0055 & $-1.28 \mathrm{E}+06$ & 2.394 & Gronvold (1976) \\
\hline Pargasite & $\mathrm{Na}\left(\mathrm{Ca}_{2} \mathrm{Mg}_{4} \mathrm{Al}\right)\left(\mathrm{Al}_{2} \mathrm{Si}_{6}\right) \mathrm{O}_{22}(\mathrm{OH})_{2}$ & -11910710 & 669.44 & 861.07 & 0.1743 & $-2.10 \mathrm{E}+07$ & 27.350 & S98 \\
\hline Fe-pargasite & $\mathrm{Na}\left(\mathrm{Ca}_{2} \mathrm{Fe}_{4} \mathrm{Al}\right)\left(\mathrm{Al}_{2} \mathrm{Si}_{6}\right) \mathrm{O}_{22}(\mathrm{OH})_{2}$ & -10569566 & 776.13 & 893.58 & 0.1799 & $-1.98 \mathrm{E}+07$ & 27.990 & S98 \\
\hline Prehnite & $\mathrm{Ca}_{2} \mathrm{Al}_{2} \mathrm{Si}_{3} \mathrm{O}_{10}(\mathrm{OH})_{2}$ & -5816166 & 271.96 & 383.25 & 0.1582 & $-8.20 E+06$ & 14.033 & 598 \\
\hline Pyrite & $\mathrm{FeS}|0| \mathrm{S}|-2|$ & -160218 & 52.93 & 74.81 & 0.0055 & $-1.28 \mathrm{E}+06$ & 2.394 & 598 \\
\hline Pyrrhotite & FeS|-2| & -100767 & 60.29 & 72.80 & 0.0000 & $0.00 E+00$ & 1.820 & S98 \\
\hline Quartz & $\mathrm{SiO}_{2}$ & -856239 & 41.34 & 46.94 & 0.0343 & $-1.13 E+06$ & 2.269 & 598 \\
\hline Ca-Fe_saponite & $\mathrm{Ca}_{0.19} \mathrm{Fe}|2|_{2.62} \mathrm{Al}_{0.38} \mathrm{Si}_{3.24} \mathrm{Al}_{0.76} \mathrm{O}_{10}(\mathrm{OH})_{2}$ & -4777570 & 429.68 & 355.41 & 0.2305 & $-7.00 E+06$ & 17.925 & This study \\
\hline Ca-Mg_saponite & $\mathrm{Ca}_{0.19} \mathrm{Mg}_{2.62} \mathrm{Al}_{0.38} \mathrm{Si}_{3.24} \mathrm{Al}_{0.76} \mathrm{O} 10(\mathrm{OH})_{2}$ & -5676610 & 335.99 & 352.40 & 0.2199 & $-8.00 E+06$ & 17.925 & This study \\
\hline Na-Fe_saponite & $\mathrm{Na}_{0.38} \mathrm{Fe}|2|_{2.62} \mathrm{Al}_{0.38} \mathrm{Si}_{3.24} \mathrm{Al}_{0.76} \mathrm{O}_{10}(\mathrm{OH})_{2}$ & -4773700 & 435.46 & 358.06 & 0.2346 & $-7.00 E+06$ & 17.925 & This study \\
\hline Na-Mg_saponite & $\mathrm{Na}_{0.38} \mathrm{Mg}_{2.62} \mathrm{Al}_{0.38} \mathrm{Si}_{3.24} \mathrm{Al}_{0.76} \mathrm{O} 10(\mathrm{OH})_{2}$ & -5674020 & 346.04 & 355.05 & 0.2240 & $-8.00 E+06$ & 17.925 & This study \\
\hline SiO2-amorphous & $\mathrm{SiO}_{2}$ & -848900 & 60.00 & 24.81 & 0.1975 & $-9.53 E+06$ & 2.900 & 598 \\
\hline Siderite & $\mathrm{FeCO}_{3}$ & -679540 & 105.02 & 48.66 & 0.1121 & $0.00 E+00$ & 2.938 & S98 \\
\hline Sulfur & $\mathrm{S}|0|$ & 0 & 31.80 & 14.98 & 0.0261 & $0.00 E+00$ & 1.561 & 598 \\
\hline Wairakite & $\mathrm{Ca}\left(\mathrm{Al}_{2} \mathrm{Si}_{4}\right) \mathrm{O}_{12}\left(\mathrm{H}_{2} \mathrm{O}\right)_{2}$ & -6181576 & 439.74 & 420.07 & 0.1861 & $-6.87 E+06$ & 18.687 & S98 \\
\hline Wollastonite & $\mathrm{CaSiO}_{3}$ & -1544837 & 82.01 & 111.46 & 0.0151 & $-2.73 E+06$ & 3.993 & 598 \\
\hline
\end{tabular}

$\Delta G_{f}^{\circ}$ is the standard Gibbs energy of formation, $S^{\circ}$ is the standard absolute entropy, $V^{\circ}$ is the molar volume, all taken per mole at 1 bar $25 C ; a, b$, and $c$ are the empirical coefficients of the heat capacity function $C p^{\circ}(T)$ $=a+b T+c / T$. S98 refers to the SUPCRT98 database (Shock et al. 1997) 
The chemical thermodynamic system was set up for $\mathrm{Al}, \mathrm{C}, \mathrm{Ca}, \mathrm{Cl}, \mathrm{Fe}, \mathrm{H}, \mathrm{K}, \mathrm{Mg}, \mathrm{Na}$, $\mathrm{O}, \mathrm{S}, \mathrm{Si}$, charge, assuming the overall charge neutrality. The properties of aqueous species and gases with their standard thermodynamic properties (and HKF EoS parameters for aqueous species) were taken from the SUPCRT98 database (Shock et al. 1997). Aqueous activity coefficients were calculated by GEM-Selektor v.3 by using the extended Debye-Hückel equation consistent with SUPCRT98 data and HKF EoS, with the common ion size parameter equal to $0.372 \mathrm{~nm}$ and the third parameter $b_{g}$ equal to 0.064 (as for $\mathrm{NaCl}$ electrolyte). The stability and mixing in the non-ideal gaseous fluid were calculated using the Peng-Robinson-Stryjek-Vera (PRSV) multicomponent fluid model (Stryjek and Vera 1986; Zezin et al. 2011).

The presence of smectites had been widely evidenced in Icelandic hydrothermal systems, but there is a lack of their accurate identification. Chemical analysis indicates a high content of Mg and Fe (Sveinbjörnsdottir 1992; Ehlmann et al. 2012; Gysi and Stefansson 2012a; Alfredsson et al. 2013), which is compatible with a saponite structure. Saponites are very common corrosion products of basaltic glass alteration (Thien et al. 2010 and references therein) under anoxic or oxic weathering conditions (Catalano 2013). Montmorillonites have been sometimes identified, mainly in the near-surface acid leaching zone (Kristmannsdottir 1979; Markusson and Stefansson 2011). We therefore consider that secondary smectites are, in fact, saponites. Noting that basalt has the same $\mathrm{Si} / \mathrm{Al}$ ratio as basaltic glass, we assumed that the $\mathrm{Si} / \mathrm{Al}$ ratio of smectites is the same as the $\mathrm{Si} / \mathrm{Al}$ ratio of primary basaltic glass (Thien 2014).

The repartition of $\mathrm{Al}$ between tetrahedral sheet and octahedral sheets was assumed to be the same as in smectites of similar stoichiometry (Thien et al. 2010). The rest of the octahedral sheet can be filled with Fe and Mg. We used ideal solid solutions with both Fe and Mg end-members, allowing Mg/Fe content in the octahedral sheet to vary. In Icelandic hydrothermal systems, the smectite interlayer space is mainly occupied with $\mathrm{Ca}$, and partially with $\mathrm{Na}$ in the presence of salt water (Sveinbjörnsdottir 1992). So, we considered two solid solutions, one containing $\mathrm{Ca}$ as interlayer cation, and the other one containing $\mathrm{Na}$ as interlayer cation.

The knowledge of molar volumes is fundamental to calculate the porosity evolution in the system, especially considering that smectites are important secondary minerals involved. For thermodynamic calculations, the molar volume was obtained considering the basal spacing (001) of a similar phase (Thien et al. 2010). Saponite showing such a basal spacing value contains in fact one layer of water (Rinnert et al. 2005), although two or even layers of water can exist in the interlayer (Ferrage et al. 2010), triggering a swelling, and therefore increasing the molar volume. The degree of hydration increases with temperature and, to a less extent, with pressure (Schleicher et al. 2013). Vidal and Dubacq (2009) claim the contrary, but they considered in their modeling a decrease of water activity with temperature increase, whereas Schleicher et al. (2013) performed their experiments in humidity chamber. Also, an increase in the saponite layer charge enhances the interlayer hydration (Michot et al. 2005).

Karmous et al. (2009) conducted hydration experiments at standard pressure and temperature by forcing the relative humidity $(90 \%)$ on saponites similar to those considered (i.e., the same layer charge). His results indicate the incorporation of two layers of water, leading to a potential maximal expansion of the basal spacing at $16.32 \AA$ when $\mathrm{Ca}$ is in the interlayer sheet, and $14.99 \AA$ when $\mathrm{Na}$ is in the interlayer sheet. For 
saponites used in this study, this hydration corresponds to molar volumes of $238 \mathrm{~cm}^{3}$ / $\mathrm{mol}$ and $218 \mathrm{~cm}^{3} / \mathrm{mol}$, respectively. There is no clear evidence in the literature whether such samples can incorporate a third layer of water at temperatures and pressures considered in this study. Considering that the interlayer charge of our smectites is relatively low compared to montmorillonites, and the fact that smectites found in the San Andreas Fault (2.7- $\mathrm{km}$ depth) contain two layers of water in spite of the pressure of 800 bar (Schleicher et al. 2013), we can reasonably assume (at pressures and temperatures considered in this study) a maximum of two layers of water in saponites. For porosity calculations, we therefore considered molar volumes established considering two layers of water.

An amorphous gel phase inherent to glass alteration (e.g., Gin et al. 2001) was not taken into the model, since its composition and thermodynamic parameters are not known. The gel phase can be accounted for by amorphous silica, diaspore, boehmite, gibbsite, and probably secondary smectites because the composition of the gel is close to the composition of crystallized secondary minerals (Thien et al. 2012).

Ideal solid solutions were also considered for other mineral phases: chabazite which includes the $\mathrm{Ca}$ end-member and the $\mathrm{Na}$ end-member; heulandite which includes the $\mathrm{Ca}$ end-member and the $\mathrm{Na}$ end-member; chlorite which includes the daphnite endmember and the clinochlore end-member; and amphibole which includes the pargasite end-member and the Fe-pargasite end-member. Details about solid solutions and their implementation in GEM-Selektor v.3 are given in Kulik et al. (2010) and Wagner et al. (2012).

Thermodynamics only indicates if considered minerals can precipitate or not but does not provide any information about the precipitation rates. A slowly precipitating phase may never be observed if there is a rapidly precipitating phase of similar composition, even though thermodynamics predicts that one phase is more stable and the faster precipitating one is more soluble. Even if sufficient time is given to the reaction to proceed, the fast precipitation of a more soluble mineral may decrease the supersaturation of the solution relative to the less soluble one, thus impeding the nucleation and growth of the less soluble mineral with a sluggish kinetics.

For instance, chlorites systematically appear in the modeling results at any temperature, whereas in reality they are only observed at temperatures above $200{ }^{\circ} \mathrm{C}$ (e.g., Kristmannsdottir 1979; Gysi and Stefansson 2012a, 2012b). Smectites are normally present at low temperature instead of chlorites. Hence, we had to block the precipitation of chlorites at temperatures below $200{ }^{\circ} \mathrm{C}$, allowing the precipitation of smectites and therefore making the model more realistic. The minerals suppressed in the model at different temperatures are indicated in Table 6. This is a very primitive account for mineral-water reaction kinetics to circumvent the absence of detailed kinetic rate equations in the model; one of the further improvements of the model would be the implementation of realistic dissolution and precipitation kinetic rates. We assume that not accounting for accurate kinetic rates does not qualitatively change the results regarding the final mineral volumes.

\section{Sequential reactor model setup}

In order to simulate rock alteration upon fluid circulation, a batch reactor calculation was set up with the process script in GEM-Selektor v.3 code. This simplified reactive transport model consists of a single flow-through box containing the fluid and solid 
Table 6 Secondary minerals disabled to account for their very slow precipitation kinetics

\begin{tabular}{|c|c|c|c|c|c|}
\hline $50^{\circ} \mathrm{C} ; 5 \mathrm{MPa}$ & $100{ }^{\circ} \mathrm{C} ; 10 \mathrm{MPa}$ & $150{ }^{\circ} \mathrm{C} ; 15 \mathrm{MPa}$ & $200{ }^{\circ} \mathrm{C} ; 20 \mathrm{MPa}$ & $250^{\circ} \mathrm{C} ; 25 \mathrm{MPa}$ & $300{ }^{\circ} \mathrm{C} ; 30 \mathrm{MPa}$ \\
\hline Quartz & Quartz & Quartz & & & \\
\hline K-feldspath & K-feldspath & K-feldspath & & & \\
\hline Albite_low & Albite_low & Albite_low & & & \\
\hline Clinochlore & Clinochlore & Clinochlore & Clinochlore & & \\
\hline Daphnite & Daphnite & Daphnite & Daphnite & & \\
\hline Prehnite & Prehnite & Prehnite & Prehnite & & \\
\hline Epidote & Epidote & Epidote & Epidote & & \\
\hline Wollastonite & Wollastonite & Wollastonite & Wollastonite & & \\
\hline Fe-pargasite & Fe-pargasite & Fe-pargasite & Fe-pargasite & & \\
\hline Pargasite & Pargasite & Pargasite & Pargasite & & \\
\hline Grossular & Grossular & Grossular & Grossular & & \\
\hline Hedenbergite & Hedenbergite & Hedenbergite & Hedenbergite & & \\
\hline Pyrite & Pyrite & Pyrite & & & \\
\hline Pyrrhotite & Laumontite & Wairakite & & & \\
\hline Magnesite & Wairakite & & & & \\
\hline \multicolumn{6}{|l|}{ Hydromagnesite } \\
\hline \multicolumn{6}{|l|}{ Dolomite } \\
\hline \multicolumn{6}{|l|}{ Siderite } \\
\hline \multicolumn{6}{|l|}{ Laumontite } \\
\hline Wairakite & & & & & \\
\hline
\end{tabular}

The cut-offs for mineral precipitation were selected following Gudmundsson and Arnorsson (2005) and Marks et al. (2010)

phases. The initial composition in terms of solid to fluid ratio is chosen such that fluid and solid phase volumes represent a porous rock with a desired porosity. The system is equilibrated, and after each equilibration step, the bulk of the equilibrated fluid phase $\left(1 \mathrm{dm}^{3}\right)$ is replaced with a fluid with the initial composition, while the reacted solid phases are retained from the previous step. The initial fluid composition is either freshwater or seawater (with or without volcanic gas), pre-equilibrated with the same mass of protolith as the initial one.

For a given volumetric fluid flow rate per unit area, each of these so-called pore water exchange cycles can be associated with a certain equilibration time, which in addition allows to calculate kinetic constraints for mineral dissolution/precipitation (though this functionality was not used in the present study). The system is not constrained to a constant volume, because the volume of fluid phase is kept constant, while the volume of solid phase aggregate was allowed to vary. As the fluid volume is kept constant, the effective porosity would change with each flow and equilibration cycle. Therefore, the time associated with each cycle for a constant Darcy flux is also changing. Actually, for the same liquid flux, a porosity change implies a change of fluid velocity. Different fluid velocities imply different contact times. We made the assumption that the liquid flux is always the same. In reality, porosity changes might also imply changes of liquid flux, which can only be resolved in a fully coupled reactive transport model in which porosity changes imply permeability changes. In a primitive flow-through reactor model, it is even possible to accumulate precipitates in an unphysical way such that the overall solid volume exceeds the initial total volume. In a realistic volume-constrained system, 
this would cause the porosity clogging that would diminish the volume occupied by the fluid phase, thus stopping the system evolution. However, to make the comparison between the different cases easier, we have made the choice of not stopping the calculations when the total volume of the system becomes unrealistic. In case of unrealistic volume since the first calculation step, it would be difficult to represent the contributions of various secondary minerals. In addition, it would not be satisfactorily for the cases where the total mineral volume is just below or just above the maximum volume limit. This part is rather a sensitivity study than a predictive model of the reality.

This approach implies that there is a correlation between porosity and permeability and that porosity changes lead to permeability changes. This simplification is necessary, but reasonable, as discussed in the introduction. The goal of this study was to investigate the alteration contrast between those two rock formations, rather than to build a model which predicts the detailed evolution of any possible intermediate case.

For the initial systems, we considered three rock types: "low-porosity" basalt (10\% porosity), "high-porosity" basalt (40\% porosity), and hyaloclastite (basaltic glass with $60 \%$ porosity). We always used $1 \mathrm{dm}^{3}$ of fluid, which was equilibrated with mineral volumes of $9 \mathrm{dm}^{3}, 1.5 \mathrm{dm}^{3}$, and $0.67 \mathrm{dm}^{3}$, respectively. Values of temperature and hydrostatic pressure vary as a function of the depth of the magma intrusion and the density of the rocks, respectively. In the present context, we approximated linear gradients of $10 \mathrm{MPa} / 1000 \mathrm{~m}$ and $100{ }^{\circ} \mathrm{C} / 1000 \mathrm{~m}$ (Marks et al. 2010, Fig. 3). For each rock type, we considered temperatures and pressures of $50{ }^{\circ} \mathrm{C}$ and $5 \mathrm{MPa} ; 150{ }^{\circ} \mathrm{C}$ and $15 \mathrm{MPa} ; 250{ }^{\circ} \mathrm{C}$ and $25 \mathrm{MPa}$, to mimic a linear increase of temperature and pressure with depth.

In addition to this single-box reactor setup, a multi-box-flux sequential reactor setup was used (Fig. 1). The principle is the same, but the water equilibrated in a given box is transferred to the next box at each time step by a zero-order (constant) flux. The input water source is constant, not pre-equilibrated with the protolith. The multi-box approach reveals possible alteration fronts. Actually, because water composition is buffered by minerals, the mineralogy (and therefore mineral volumes) may change along the distance traveled by water.

\section{Kinetic model for basaltic glass dissolution}

In fresh water, the dissolution rate of silicate glass is at its maximum. Upon this process, the solution is progressively loaded with dissolved silica. Simultaneously, an amorphous gel layer precipitates and the dissolution rate drops to a low value, the residual rate. The residual rate is several orders of magnitude lower than the initial rate (Techer et al. 2001). The gel acts as a diffusion barrier by limiting the transport of water from the solution to the fresh glass (e.g., Rebiscoul et al. 2004). It makes the glass

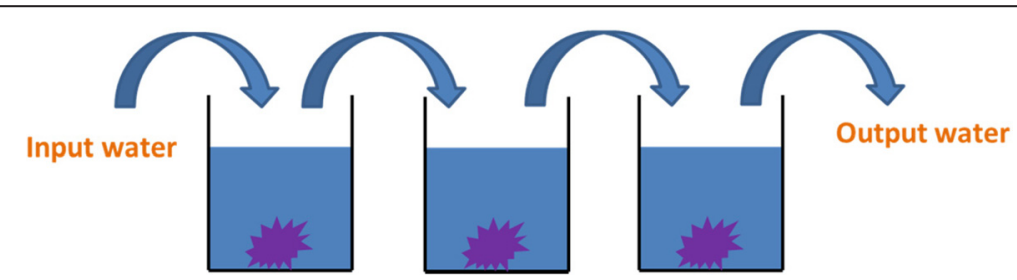

Fig. 1 The reactive transport model setup. After each time step, the water that has reacted in a given box is moved to the next box or lost in the output. The water is replaced by that from the previous box or the input water (constant initial composition) 
very durable; for instance, basaltic glasses may survive for millions of years under lowtemperature subsurface conditions (Crovisier et al. 2003). The gel alteration layer of basaltic glass is commonly called "palagonite". The secondary phase precipitation constitutes a sink of silica, and can therefore decrease the gel thickness, and therefore increase the dissolution rate (e.g., Thien et al. 2012).

At equilibrium, minerals are constantly subject to a gross forward precipitation rate and a gross backward dissolution rate (e.g., Thien et al. 2014). Considering glass, there is no gross forward precipitation rate (i.e., glass cannot re-precipitate) because the glass can only be formed by fast cooling of a melt, which is not possible in the context of hydrothermal alteration. This implies that the equilibrium between glass and aqueous solution will never be reached, even in the case of strong silica saturation in the solution. Glass can only dissolve, even though very slowly. This specific feature makes determination of the glass "solubility" senseless; conversely, the glass alteration kinetics cannot rigorously be modeled using a classical kinetic equation involving solubility constants or saturation indices. Therefore, many authors replaced the glass solubility by the gel solubility (Techer et al. 2001; Gysi and Stefansson 2011). But the stoichiometry and the solubility of the gel are difficult to estimate, and the problem can be simplified by considering amorphous silica or aluminum hydroxide (e.g., Bourcier et al. 1990). Those models are able to describe experimental data in far-fromequilibrium cases and can also describe the drop of the alteration rate, but cannot be used at close-to-equilibrium conditions because a residual alteration rate is not accounted for.

A way to circumvent this problem is to add a constant term related to the residual rate (Strachan and Neeway 2014). A complete model of glass dissolution had been developed, the GRAAL model (Frugier et al. 2008). This model considers an instantaneous hydration (i.e., alteration) of the glass. As soon as a part of the glass is altered, the increase of silica aqueous concentration triggers the formation of the gel. The gel limits the transport of water from the solution to the glass (diffusion barrier); the alteration rate consequently decreases. The precipitation of secondary phases (which influence the thickness of the gel via silicium mass balance) is accounted for. But GRAAL is a reactive transport model working at the scale of the glass grain. It is currently not possible to embed this reactive transport model into another reactive transport model working at the scale of the hydrothermal system.

The simplest approach would be to consider a constant dissolution rate. Actually, a compilation of measured basaltic glass dissolution rates (Grambow et al. 1986) indicates at Earth surface conditions an average value between 3 and $20 \mu \mathrm{m} / 1000$ years in fresh water, and $0.1 \mu \mathrm{m} / 1000$ years in silica-saturated water. The difference between those two conditions is about two orders of magnitude. The water located inside the hydrothermal system has already interacted with rocks. Hence, realistic glass dissolution rate in hydrothermal systems may be closer to that in the silica-saturated water rate than this of the fresh water. We therefore consider the average dissolution rate of a basaltic glass of $0.1 \mu \mathrm{m} / 1000$ years. The relation between a linear dissolution rate $V(\mathrm{~m} / \mathrm{s})$ and a growth rate normalized to the surface $R_{p}\left(\mathrm{~mol} / \mathrm{m}^{2} / \mathrm{s}\right)$ is:

$$
V=\frac{M}{d} \times 10^{-6} \times R_{p}
$$

where $M$ is the molar mass of the glass $(\mathrm{g} / \mathrm{mol})$ and $d$ is the glass density $\left(\mathrm{g} / \mathrm{cm}^{3}\right)$. By applying this equation, the rate of $0.1 \mu \mathrm{m} / 1000$ years corresponds to $7.7^{\circ} 10^{-14} \mathrm{~mol} / \mathrm{m}^{2} / \mathrm{s}$. By considering an average surface temperature of $5{ }^{\circ} \mathrm{C}$ corresponding to those data, 
alteration rates can be recalculated at each temperature using the activation energy. The activation energy of basaltic glass dissolution is of $72 \mathrm{~kJ} / \mathrm{mol}$ (Crovisier et al. 2003), nearly the same as that for nuclear waste glass dissolution (e.g., Adocat et al. 2001). This value is able to accommodate the temperature variations of basaltic glass dissolution rates measured by Gislason and Oelkers (2003), at a given $\mathrm{pH}$, for temperature ranges between 0 and $300{ }^{\circ} \mathrm{C}$. By considering the datasets obtained at $\mathrm{pH}$ between 4 and 10, the average uncertainty is of one order of magnitude. The considered equation giving the amount of dissolved glass is:

$$
m_{a(\Delta t)}=S_{(t)} \times e^{\frac{-E}{R}\left(\frac{1}{T}-\frac{1}{278}\right)} \times R_{p} \times \Delta t \times M
$$

where $m_{a(\Delta t)}$ is the mass of glass altered (g) during the considered time interval $\Delta t(\mathrm{~s})$, $S_{(t)}$ is the surface of the glass $\left(\mathrm{m}^{2}\right), E$ is the activation energy of the glass $(\mathrm{J} / \mathrm{mol}), R$ is the gas constant $(8.314 \mathrm{~J} / \mathrm{mol} / \mathrm{K})$, and $T$ is the temperature $(\mathrm{K})$.

The surface of the glass is recalculated at each time step:

$$
S_{(t)}=S_{S(t)} \times m_{(t)}
$$

where $S_{s(t)}$ is the specific surface area $\left(\mathrm{m}^{2} / \mathrm{g}\right)$ and $m_{(t)}$ the mass of glass $(\mathrm{g})$, at the time $t$.

The specific surface area is assumed to vary during the dissolution process:

$$
S_{S(t)}=S_{S(0)} \times\left[\frac{m_{(0)}}{m_{(t)}}\right]^{\frac{1}{3}}
$$

where $S_{S(0)}$ is the initial specific surface area $\left(\mathrm{m}^{2} / \mathrm{g}\right)$, and $m_{(0)}$ the initial mass of glass (g). This spherical model is the simplest way to account for the specific surface area increase during dissolution. Nevertheless, possible morphological changes make the reality more complex.

When not measured by BET, the specific surface area is estimated as follows:

$$
S_{S(0)}=S R F \times \frac{3}{d \times r}
$$

where $S R F$ is the surface roughness factor (unitless), and $r$ the average grain radius $(\mathrm{cm})$. The surface roughness factor accounts for the fact that grains are nor perfectly spherical. It was defined by Wolff-Boenisch et al. (2004) as the ratio between specific surface area measured by BET and geometric specific surface area. In case of perfectly smooth and calibrated grains, the surface roughness factor is equal to 1; otherwise it is greater than 1. A collection of Icelandic grain glasses indicates a surface roughness factor between 3 and 206 (Wolff-Boenisch et al. 2004).

The calculations were performed with an Excel $^{\circ}$ spreadsheet. The time step length was manually optimized, in order to limit the amount of calculations. It varies from 0.1 to 100,000 days, depending on the total time.

\section{Results and discussion}

\section{Mineralogical evolution and volume changes}

The volume evolution of different minerals is presented in Figs. 2, 3, 4, 5 and 6. The replacement of water performed at each time step corresponds to one pore water exchange cycle. The initial volumes of protoliths were $9 \mathrm{dm}^{3}, 1.5 \mathrm{dm}^{3}$, and $0.67 \mathrm{dm}^{3}$, respectively, for low-porosity basalt, high-porosity basalt, and hyaloclastite. The initial volume of water was always $1 \mathrm{dm}^{3}$. 


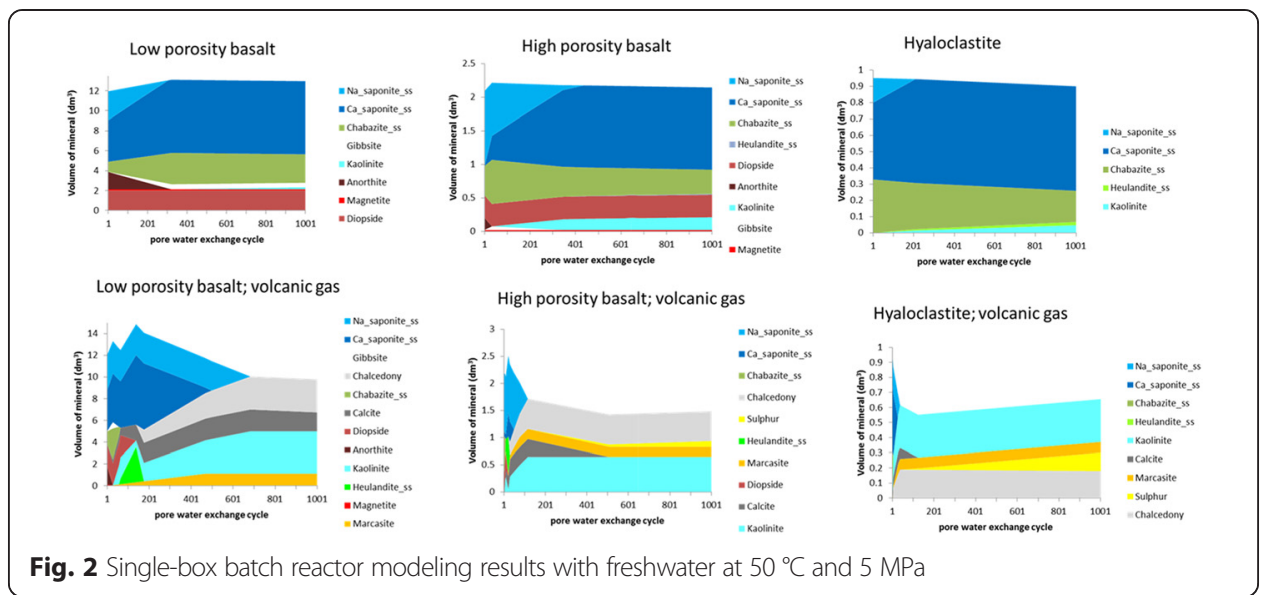

\section{Model of leaching in freshwater}

At $50{ }^{\circ} \mathrm{C}$ and $5 \mathrm{MPa}$, the primary basalt is already severely altered after the first pore water exchange cycle; in each case, fayalite, forsterite, and enstatite are fully dissolved (Fig. 2). For hyaloclastite, the basaltic glass does evidently no longer exist at the first pore water exchange cycle, because thermodynamic equilibrium is considered. In the presence of volcanic gas, the whole primary basalt is nearly completely altered at the beginning of the simulation (at least $70 \%$ in volume, after the first pore water exchange cycle). The more the initial porosity the more the primary rock is altered. Without volcanic gas, the predominant minerals are saponite and chabazite (low-temperature zeolite). With volcanic gas, saponites and zeolites are less abundant; they are replaced by chalcedony, kaolinite, and carbonates. In such a case, marcasite and sulfur are always present. The mineral volume of the low-porosity basalt systems is always greater than the initial value of $10 \mathrm{dm}^{3}$ : in those systems, the whole initial porous volume is filled by secondary minerals, whereas it is not the case considering high-porosity basalt systems (altered mineral volume less than the initial value of $2.5 \mathrm{dm}^{3}$ ). For hyaloclastites, the final mineral volume is largely less than the limit of $1.67 \mathrm{dm}^{3}$ (i.e., the initial volume or the total volume available).

At $150{ }^{\circ} \mathrm{C}$ and $15 \mathrm{MPa}$ (Fig. 3), the results are similar to those at $50{ }^{\circ} \mathrm{C}$ and $5 \mathrm{MPa}$. Nevertheless, there is a difference for the hyaloclastite system: in the presence of volcanic gas, the mineral volume decreases with time (from the first pore water exchange cycle).

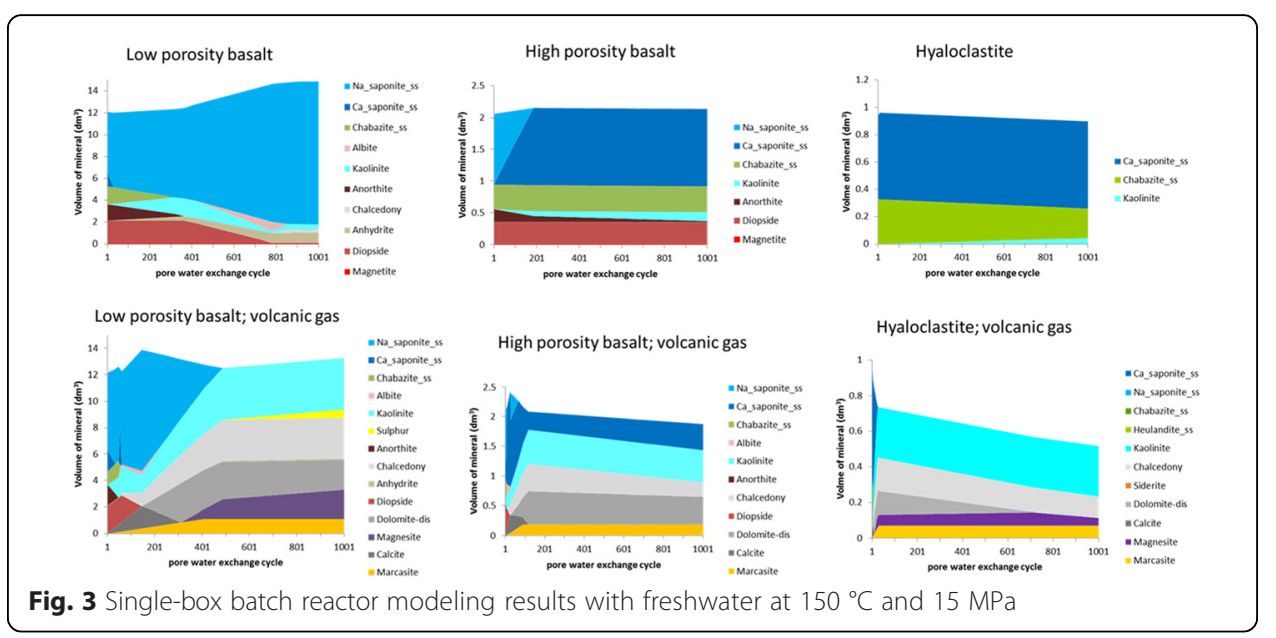




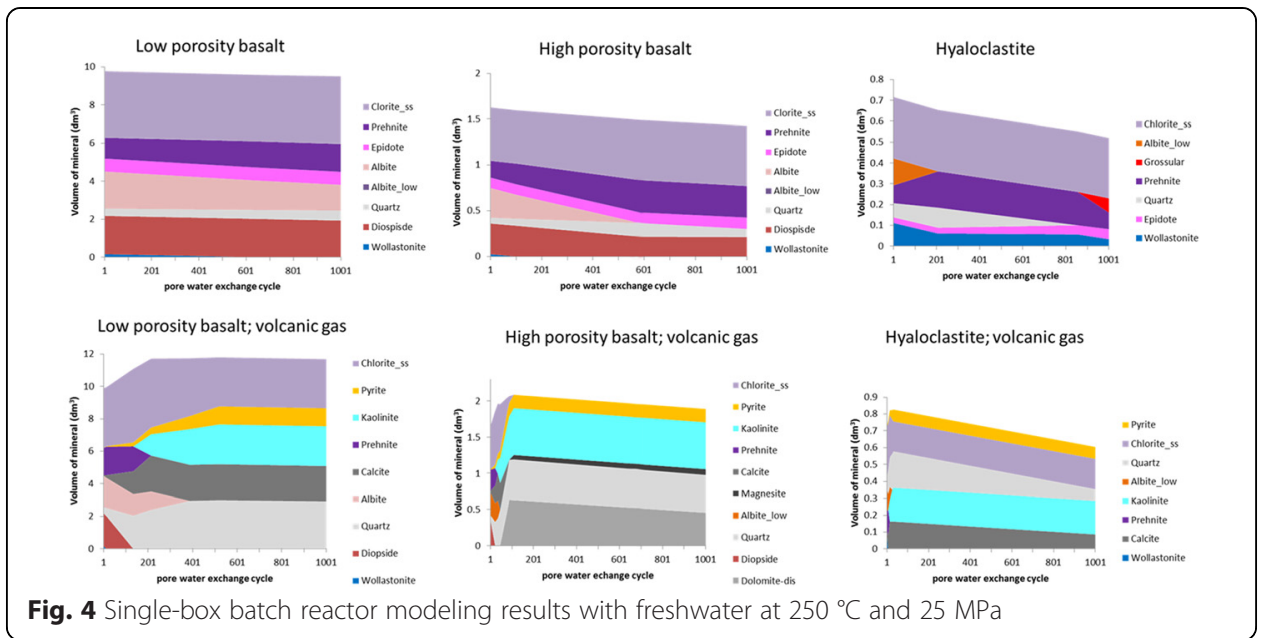

At $250{ }^{\circ} \mathrm{C}$ and $25 \mathrm{MPa}$, chlorites are the most abundant secondary minerals (Fig. 4). They are less abundant in the presence of volcanic gas. The presence of volcanic gas favors the precipitation of kaolinite, carbonates, and quartz and disfavors the precipitation of prehnite and wollastonite. Epidote never appears in the presence of volcanic gas; whereas pyrite is always present. The primary basaltic minerals diopside and albite are less stable in the presence of volcanic gases. In low-porosity basalt, the volume of secondary minerals exceeds the initial volume of the solid. Considering high-porosity systems, the pore space is not completely filled by secondary minerals; the mineral volume decreases with the time in hyaloclastite systems (from the first pore water exchange cycle).

\section{Model of leaching in seawater}

At $50{ }^{\circ} \mathrm{C}$ and $5 \mathrm{MPa}$, the evolution is similar as in the freshwater case (Fig. 5), but is characterized by a more abundant precipitation of saponites and a less important precipitation of zeolites. Basalt minerals are less stable in seawater than in freshwater. With seawater and volcanic gas, the precipitation of sulfur is important and occupies a considerable part of the volume for low-porosity basalt and hyaloclastite. In those systems, the pore space can be completely filled by secondary minerals after sufficient number of pore water exchange cycles.

At $250{ }^{\circ} \mathrm{C}$ and $25 \mathrm{MPa}$, the evolution is also similar to that in the freshwater case (Fig. 6), but is characterized by larger amount of chlorites. The mineral volume for

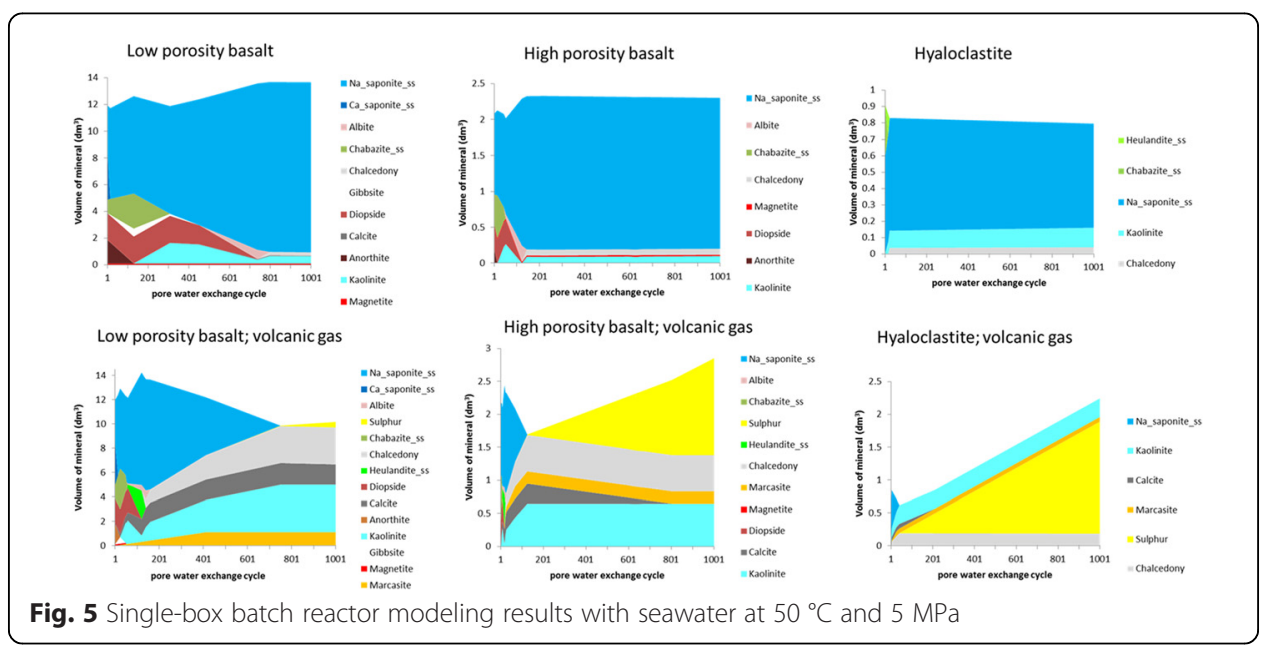




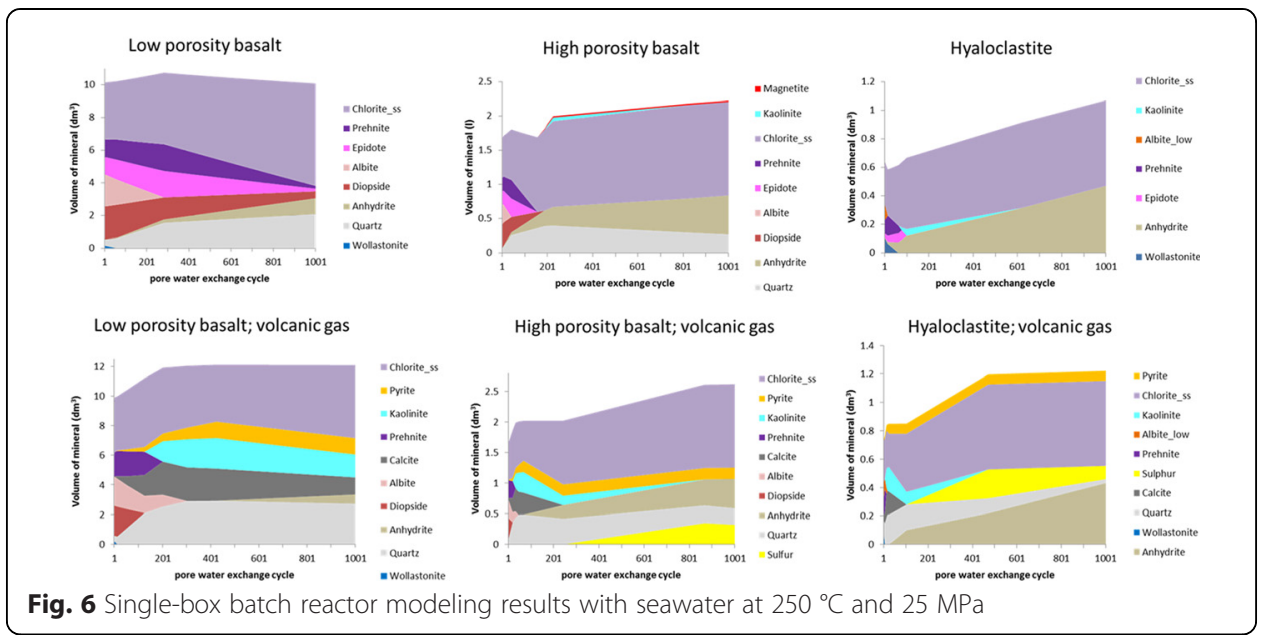

high-porosity basalt and hyaloclastite increases on the contrary to freshwater case, but the pore space is not completely filled as observed at $50{ }^{\circ} \mathrm{C}$ and $5 \mathrm{MPa}$.

\section{Discussion}

The calculations show that the presence of volcanic gas and the higher fluid/solid ratio (higher porosity) enhance the alteration of primary basalt. The complete dissolution of primary basalt at high temperatures, reported in the literature (e.g., Franzson et al. 2008), seems to be supported by this modeling, at least when volcanic gases are involved. For albite being usually stable at high temperatures, it is difficult to evaluate which part comes from the protolith, and which part is secondary. Actually, at those conditions, feldspars can be primary minerals as well as secondary minerals (Larsson et al. 2002). Basalt primary minerals appear to be more stable in freshwater than in seawater. Main secondary minerals are saponites below $250{ }^{\circ} \mathrm{C}$, and chlorites above this temperature. The nature of the protolith (i.e., basalt or basaltic glass) has a limited influence on the secondary mineralogy.

The effect of dissolved gases (assumed to originate from young magma intrusions) on the alteration is significant. The presence of volcanic gas disfavors precipitation of zeolites and saponites (or chlorites above $250{ }^{\circ} \mathrm{C}$, in a less extent) and favors the precipitation of carbonates, quartz (or polymorphs like chalcedony), and kaolinite. Epidote never forms in the presence of volcanic gas, whereas pyrite and chalcedony are always observed. The secondary mineralogy appears therefore as an indicator of the conditions of the alteration. The modeling indicates that the precipitation of zeolites requires a low amount of volcanic gas and preferably freshwater than seawater. It is consistent with the observations of Kristmannsdottir (1979). Actually, she reported that zeolites are less common in areas with saline fluids. The high amount of zeolites sometimes reported in the literature is not supported by this study. Nevertheless, it had been assumed that zeolites are the consequence of progressive low-temperature metamorphism (Weisenberger and Selbekk 2009), rather than hydrothermal alteration.

The porosity evolution of the systems follows the pattern of the initial porosity of the protolith. For the low-porosity basalt, a complete filling of initial porosity by secondary minerals is systematically observed, regardless of the conditions. It could explain why certain layers of compact intrusive basalt still appear fresh: if there is no water circulating, no significant alteration can occur. The field observation reported by Weisenberger and 
Selbekk (2009), indicating that secondary minerals mainly occur in the top and bottom parts of basaltic flow units, is consistent with this concept. Actually, the high-porosity and permeability of hyaloclastites implies high liquid fluxes; this water is necessarily in contact with the edges of low-porosity basaltic flow units (but can also penetrate to them along the fractures). The water in contact with the edges of the low-porosity basalt units alters them, mineralogical changes trigger a complete closure of the porosity, and secondary minerals are therefore visible in the top and bottom parts of the basalt units, as well as in the fractures. For the high-porosity basalt, the initial porosity is decreased, but the volume of precipitates is not enough to block the transport in the system. The interpretation of those results is not certain. In fact, below $250{ }^{\circ} \mathrm{C}$ saponites are the main secondary minerals, and there are uncertainties about their molar volumes. Nevertheless, a tendency can be considered: the more the initial porosity of the basalt the less the system has the tendency to be clogged. For hyaloclastites, the porosity decrease upon alteration is negligible, except that at low temperature, in seawater systems with volcanic gas, the possibility of porosity closure after many pore water exchange cycles cannot be excluded.

By using a single-box batch reactor model, the mineralogical evolution can be followed as a function of time, but not as a function of space. In fact, the water that reacted with the rocks will react again with "less reacted rocks" because of the fluid circulation, and secondary minerals along the reaction pathway are not necessarily the same. To clarify this, the multi-box batch reactor model was used. The calculations were only done for hyaloclastites; for basalts, they do not make much sense because unrealistic volumes are obtained from the beginning of the simulation. The results at $250^{\circ} \mathrm{C}$ and $25 \mathrm{MPa}$ (Fig. 7a) show that secondary minerals and total mineral volumes are the same as when considering the single-box model (Figs. 4, 6). In addition, a mineral zonation can be seen.

Note that this simplified modeling approach is based on assumptions that are not necessarily realistic for the whole range of conditions. Firstly, we calculated water/rock ratios on the basis of the total porosity. It implies that the water can react with the total amount of protolith. This hypothesis seems to be reasonable for hyaloclastite formations, but less reasonable for lava flows in which the low permeability suggests that part of the pores are not connected. Possible modifications of the pore connectivity during the alteration (NavarreSitchler et al. 2011) were also not accounted for. Secondly, the dissolution kinetics was not accounted for: the total amount of protolith reacts instantaneously with the water. Such an approach is only true if the dissolution kinetics is fast. It might be the case for hyaloclastites because they are completely altered, but not for lava flows that are fresh. This simple modeling is not necessarily realistic, but our model is not supposed to represent the whole reality, a complex reactive transport model accounting for kinetics is necessary to approach this goal. Nevertheless, it shows the potential effect of the initial porosity (expressed as water/solid volume ratio) on the evolution of the system. Let us see for which conditions the model is realistic and propose complementary explanations for other conditions.

\section{The complete alteration of hyaloclastites}

It was previously shown by using a single-box batch reactor model that hyaloclastites could be potentially completely altered, because the transformation of glass into secondary minerals does not trigger any noticeable volume change. In this section, we firstly investigate if this complete alteration is kinetically possible. Thereafter, we investigate for which conditions the approach used in the last section is realistic. 


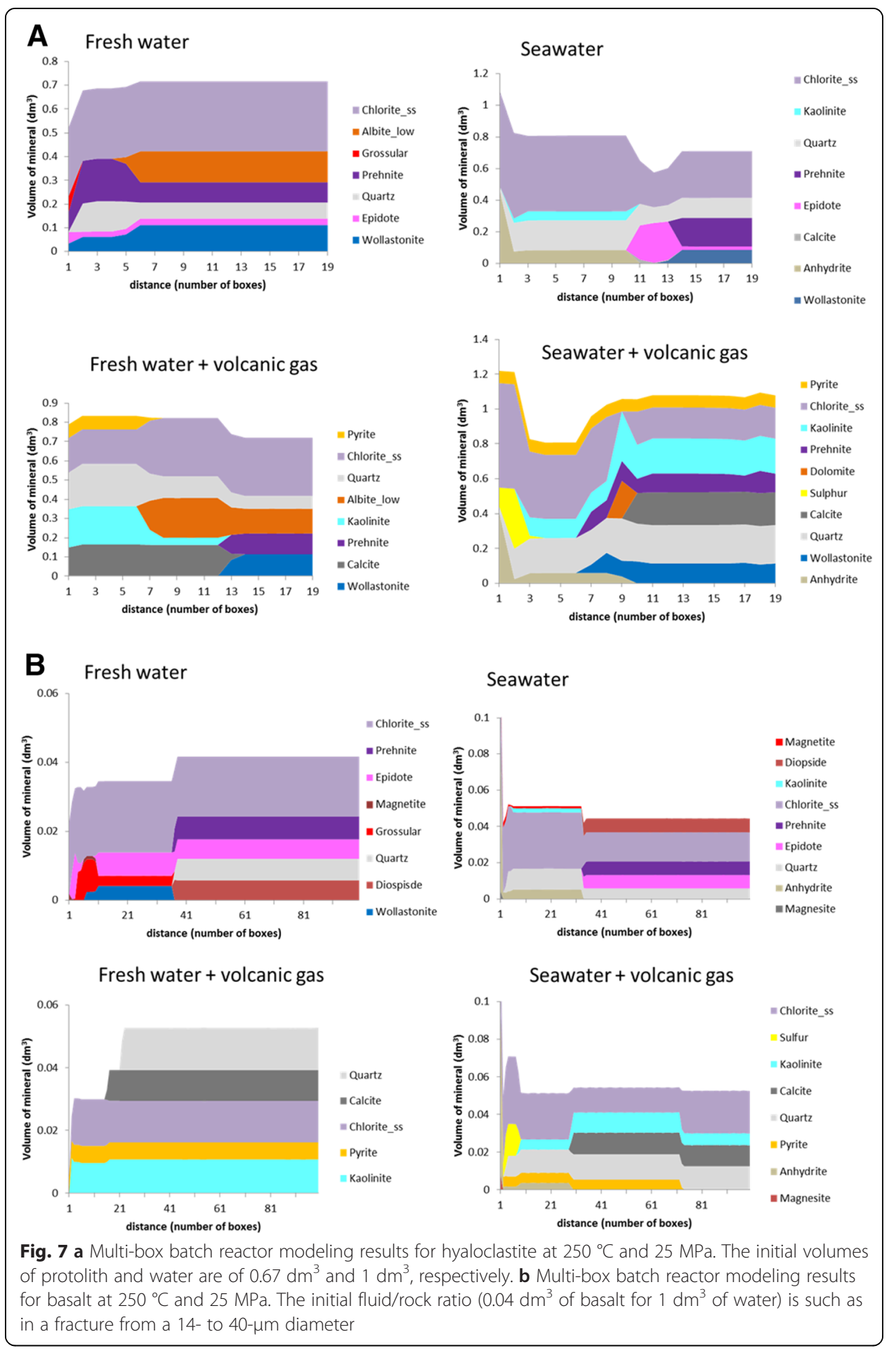

\section{Alteration times}

The model described in the "Methods" section was used to calculate the time necessary to reach $99 \%$ of the alteration as a function of surface roughness factor (SRF) (Fig. 8a) and temperature (Fig. $8 \mathrm{~b}$ ). The time necessary to the complete alteration is proportional to the grain size and also proportional to the SRF. In other words, the alteration is proportional to the specific surface area. The more the specific surface area, the faster 

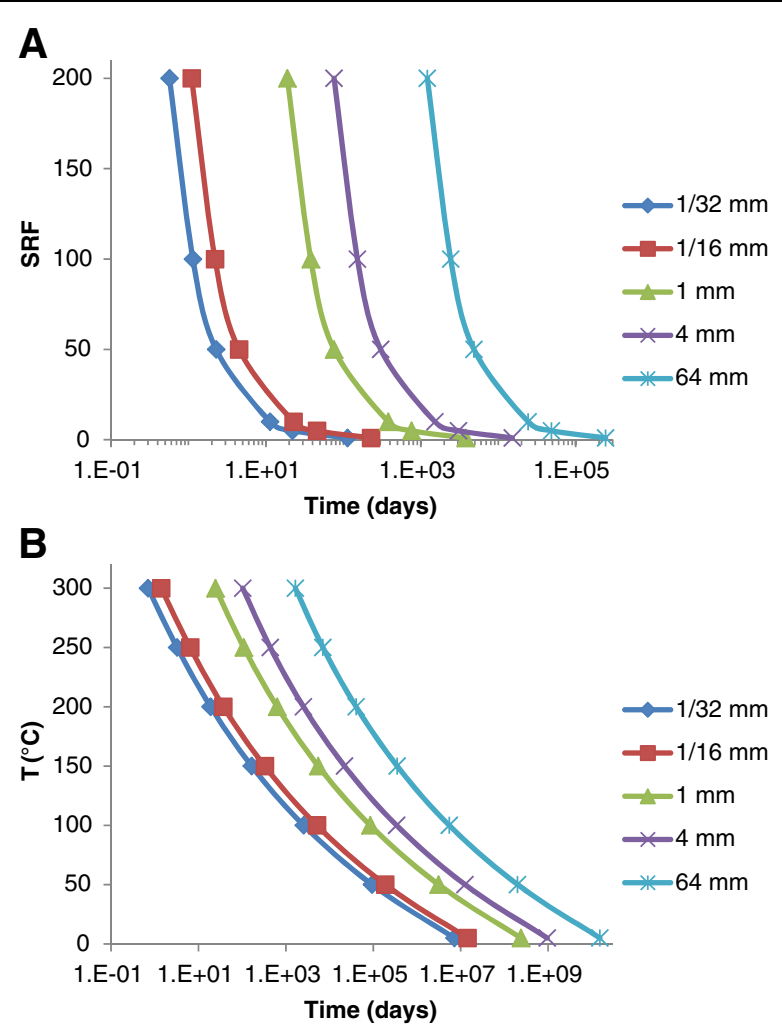

Fig. 8 a Time necessary to reach $99 \%$ of the total alteration of basaltic glass grains of different diameters, as a function of surface roughness factor (SRF), at $200{ }^{\circ} \mathrm{C}$. $\mathbf{b}$ Time necessary to reach $99 \%$ of the total alteration of basaltic glass grains of different diameters, as a function of temperature. SRF $=6$

the alteration occurs. In the considered examples, the alteration time varies up to six orders of magnitude as function of specific surface area. The effect of temperature can be more important (Fig. 8b) and does not depend on the specific surface area. Because the residual alteration rate (i.e., minimum dissolution rate) of basaltic glass was considered, the calculated alteration durations represent "upper limits". In certain cases (e.g., diluted water), alteration durations can be two orders of magnitude faster than those represented in this study.

Upon hydrothermal conditions, the alteration of glassy fragments of hyaloclastites is very fast: from a few hours to a few years. It represents a huge contrast compared to the several millions years of surface basalt life duration (Crovisier et al. 2003). In Hellisheidi, the high temperature hydrothermal circulation did not occur; hence, hyaloclastites are only partially altered (Alfredsson et al. 2008). The measurements performed in this site give an opportunity to validate the model used in this study, but the task is not trivial because of the huge geological heterogeneities and the limited amount of available data. We focus on a hyaloclastite layer located between 200- and 400-m depth. The published data indicate an average temperature of $16{ }^{\circ} \mathrm{C}$, an average alteration of $30 \%$, and a grain size of $7 \mathrm{~mm}$ in diameter (Alfredsson et al. 2013). By using these temperature and grain size data, and supposing a SRF of 6 (an average value from considering the results of Wolff-Boenisch et al. (2004)), the model presented in this study indicates that 200,000 years are necessary to alter $30 \%$ of the protolith. It is fully in accord with the age range from 125,000 to 275,000 years given by Alfredsson et al. (2013).

Nevertheless, in the considered system, the water supply is not unlimited if a given time is considered. The rock alteration consumes water, and the alteration stops if 
water is no longer available. The water is supposed to be initially present in the pore space of system and is renewed with a certain fluid velocity. If the availability of water limits the alteration, the results presented in this study do not make any sense. The amount of water necessary to completely alter $1 \mathrm{~m}^{3}$ of basaltic glass with a porosity of $60 \%$ was calculated using the GEM-Selektor v.3 package. Depending on temperature and gas content, the amount of water necessary to completely alter the basaltic glass ranges between 52 and $76 \mathrm{dm}^{3}$. It is largely inferior to $600 \mathrm{dm}^{3}$, the amount of water contained in $1 \mathrm{~m}^{3}$ of this rock. The water potentially present in the pore spaces of hyaloclastites is largely sufficient to completely achieve their alteration. It implies that fluid velocity is not necessarily a limiting parameter for the alteration of hyaloclastites.

\section{Alteration time versus fluid velocity}

In a sequential reactor simulation, the water of each box is completely replaced after equilibration with the solid at each time step. Thus, the duration of the time step corresponds to the time necessary to react with the whole amount of protolith in the node, i.e., this duration is proportional to the solid/water mass ratio in the box. Conversely, for an assumed flux of water through it, there is an optimal box size, defined by the time step duration and the characteristic diffusion length.

We considered an average value of water self-diffusion coefficient of $2.1^{\circ} 10^{-9} \mathrm{~m}^{2} / \mathrm{s}$ at $25^{\circ} \mathrm{C}$ (Harris and Woolf 1980). It is close to values established for solutes in water which vary (according to the ion species) between $0.6^{\circ} 10^{-9} \mathrm{~m}^{2} / \mathrm{s}$ and $9.3^{\circ} 10^{-9} \mathrm{~m}^{2} / \mathrm{s}$ at $25{ }^{\circ} \mathrm{C}$ (Flury and Gimmi 2002). Those authors also reported a value of $1.5^{\circ} 10^{-9} \mathrm{~m}^{2} / \mathrm{s}$ for $\mathrm{NaCl}$ electrolyte. As composition of the solution is likely to change, it is easier to consider the water self-diffusion coefficient, which in this study represents an average diffusion coefficient of solutes in water. Because the diffusion length depends on the square root of the diffusion coefficient, the uncertainties on the diffusion coefficient do not noticeably influence the results. This value has to be corrected to account for porosity. We used a simplified Archie law (the effective diffusion coefficient is equal to the porosity multiplied by the pore diffusion coefficient). The initial porosity in hyaloclastites is 0.6 , assumed to remain constant during the alteration. This implies the effective diffusion coefficient of water of $1.26^{\circ} 10^{-9} \mathrm{~m}^{2} / \mathrm{s}$ at $25^{\circ} \mathrm{C}$. Unfortunately, Harris and Woolf (1980) did not report the diffusion coefficient for temperatures higher than $100{ }^{\circ} \mathrm{C}$. But we used their data to establish the activation energy of $17 \mathrm{~kJ} / \mathrm{mol}$; thus, diffusion coefficients can be recalculated for the desired temperature. The effect of pressure is negligible in the range of pressures of interest. The distance crossed by a molecule affected by diffusion can be approximated as:

$$
e=\sqrt{D \times t}
$$

where $e$ is the distance $(\mathrm{m}), D$ the diffusion coefficient $\left(\mathrm{m}^{2} / \mathrm{s}\right)$, and $t$ the time $(\mathrm{s})$.

For each temperature, there is a length for which the diffusion velocity equals the transport velocity, and a corresponding time. If the glass can be completely altered during this time, the approach used in the "Mineralogical evolution and volume changes" section is realistic. By considering the residence time of water (Arnorsson 1995) along a hypothetical fluid pathway (going down to 3-km depth and going back to the surface), one can estimate a fluid velocity range between $1^{\circ} 10^{-7} \mathrm{~m} / \mathrm{s}$ and $1^{\circ} 10^{-5} \mathrm{~m} / \mathrm{s}$. It is consistent with the value estimated in Hellisheidi by Aradottir et al. (2012): $8^{\circ} 10^{-7} \mathrm{~m} / \mathrm{s}$. The time for which the transport equals the diffusion increases with the temperature because the diffusion coefficient increases with the temperature whereas the fluid velocity does not depend on temperature. This time is represented in Fig. 9. 


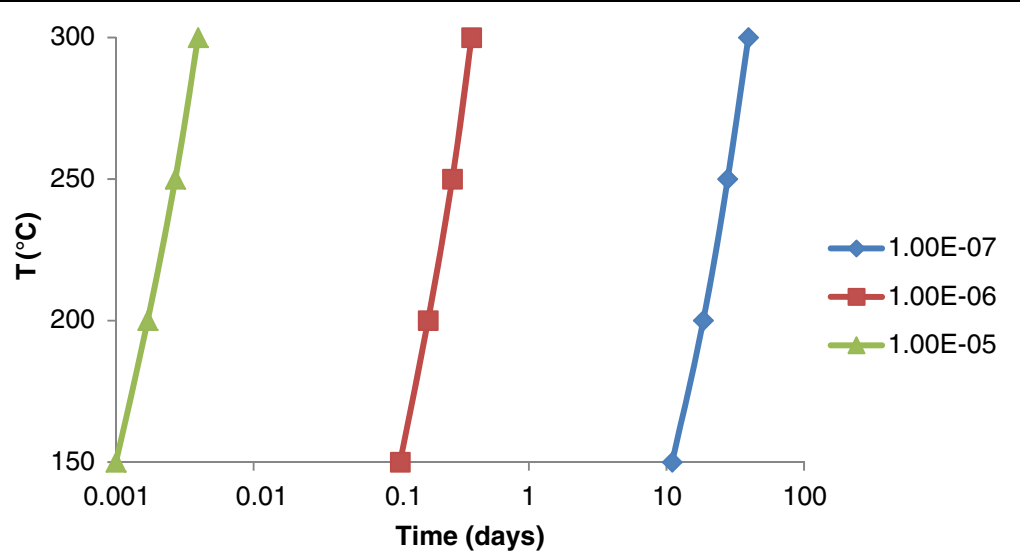

Fig. 9 Time for which the flow rate equals the diffusion, for different fluid velocities $(\mathrm{m} / \mathrm{s})$. For a given fluid velocity, when this calculated time is greater than or equal to the total dissolution time of the protolith, equilibrium dissolution can be considered

One can see that this time is very sensitive to the value of the fluid velocity. A variation of one order of magnitude of the fluid velocity influences the time by two orders of magnitude. When comparing with the alteration times given on Fig. 8, by considering an average fluid velocity of $1^{\circ} 10^{-6} \mathrm{~m} / \mathrm{s}$ and a SRF of 6 , it appears that the concept of complete dissolution and alteration is only valid for finest grain sizes at temperatures of $300{ }^{\circ} \mathrm{C}$ and above. By considering a SRF of 200 and the same fluid velocity, the concept is also valid at temperatures of $200{ }^{\circ} \mathrm{C}$. By considering the lowest values of fluid velocity, the concept is valid for a wider range of conditions, for instance for the grains of a $1 / 16-\mathrm{mm}$ diameter with a low SRF at $200{ }^{\circ} \mathrm{C}$. By considering the lowest values of fluid velocity, this concept is also valid at $150{ }^{\circ} \mathrm{C}$ if the highest possible values of specific surface area are considered (not presented on Fig. 8, but can be deduced by extrapolation, considering that the alteration time is roughly proportional to the SRF).

Our box reactor batch modeling approach is mostly valid for the highest temperature areas, from 200 to $300{ }^{\circ} \mathrm{C}$ as a function of the grain morphology. For the other cases, we consequently overestimate the amount of glass that reacts with the fluid. An alternative approach would be to increase the fluid/rock ratio, to let the amount of protolith that can be altered during a considered time react. But such an approach is not necessarily more realistic, because when the initial amount of protolith is completely altered, secondary products continue to be altered in the model, whereas in reality more protolith still dissolves. A realistic model suitable for the whole range of conditions is necessarily a complex reactive transport model accounting for mineral-water kinetic rates. We have seen that the transformation of glass into secondary minerals does not change the total mineral volume at $60 \%$ initial porosity and that the more the initial porosity the less is the mineral volume change. Letting less glass to react (i.e., equivalent to set up porosity above $60 \%$ ) cannot reduce the initial porosity, as suggested by the results presented in the "Mineralogical evolution and volume changes" section. The conclusions about hyaloclastites derived in the last section are still valid: the alteration of hyaloclastites does not affect the porosity significantly. Such alteration is typically fast because of high specific surface areas and hydrothermal temperatures. 


\section{The limited alteration of lava flows}

As seen in the introduction, in lava flows, water circulates mostly through fractures. The fractures could be formed by the cooling contraction, but also necessarily by the tectonic extension occurring in the rift zones. For hydraulic reasons, the superposition of hyaloclastite formations and lava flows necessarily implies that the water circulates faster through the lava flows than in the hyaloclastites. Consequently, the amount of water cannot be a limiting parameter for the alteration of the basalt fracture surfaces. The water slowly diffuses through the more or less connected pores, in a perpendicular direction to the fracture flux (e.g., MacQuarrie and Mayer 2005).

\section{Mineral volume changes in pores and fractures}

In our modeling approach, we assumed that porosity changes are only due to mineral volume changes and this leads to permeability changes that are positively correlated with porosity variations.

The approach developed in the "Mineralogical evolution and volume changes" section indicates that the initial fluid/rock ratio controls the evolution of the system and cannot be rigorously applied to the case of lava flows, which are not a homogeneous porous medium. Nevertheless, there should be a threshold fluid/rock ratio at which the system is clogged (i.e., the volume of secondary minerals is equal to the initial volume of protolith with voids). Above this ratio, the water circulation in the system is not blocked and the alteration can proceed. With the results presented in the "Mineralogical evolution and volume changes" section, it can be stated that the threshold ratio ranges conjugate to porosity range from 10 to $40 \%$. We calculated with GEM-Selektor v.3 that the threshold initial volumetric water/rock ratio is approximately 0.4 and barely varies with the temperature or the initial water composition. It corresponds to a total porosity of $30 \%$. By considering a range of possible specific surface areas from 0.4 to $2.3 \mathrm{~m}^{2} / \mathrm{g}$ for a fresh basalt (Simonyan et al. 2012) and a perfectly cylindrical shape for pores and fractures, it can be simply calculated that the water/rock ratio of 0.4 corresponds to a pore or fracture diameter range between 0.2 and $1.3 \mu \mathrm{m}$, completely filled by water. This is greater than the average pore diameter of $45 \mathrm{~nm}$ measured in a fresh basalt (Simonyan et al. 2012). Consequently, the pores in basalt can be potentially clogged, as well as the sub-micrometric aperture fractures.

The knowledge of permeability allows estimating the average aperture of fractures by using the cubic law for a relation between the water debit, the measured pressure gradient, and the cube of the size of the fracture plane. Combining this law with the Darcy's law yields (Committee on Fracture Characterization and Fluid Flow, National Research Council 1996):

$$
b=\left(12 \times T_{f}\right)^{\frac{1}{3}}
$$

where $T_{f}$ is the transmissivity $\left(\mathrm{m}^{3}\right)$, and $b$ the thickness of the fracture plane $(\mathrm{m})$. It is the simplest approximation considering smooth walls and regular fractures. Actually, real fractures have rough walls and variable apertures, but this reasoning still gives some insight into how much porosity/aperture reduction is possible.

Arnorsson (1995) used permeability measurements to estimate the transmissivity. He found a transmissivity in the range between $2^{\circ} 10^{-12}$ and $8^{\circ} 10^{-12} \mathrm{~m}^{3}$. The application of Equation 7 gives the average fracture aperture between 288 and $458 \mu \mathrm{m}$. It is larger than 
the threshold diameter of $<1 \mu \mathrm{m}$ as previously calculated. In other words, such fractures cannot be clogged during the alteration and contribute to the fluid circulation during the whole life of the hydrothermal system. It is important to note that calculated values are only average values. It means that smaller fractures can exist, as well as larger fractures.

The multi-box sequential reactor modeling was performed by considering a high arbitrary fluid/rock ratio. The initial volume of basalt is $40 \mathrm{~cm}^{3}$ for $1 \mathrm{dm}^{3}$ of water. It corresponds to a pore or a fracture of 14 to $40 \mu \mathrm{m}$ in diameter, depending of specific surface area. We can note that such a fluid/rock ratio can also represent a pore or a fracture of a different diameter, by considering limiting dissolution kinetics. Volcanic gas or seawater have the tendency to increase the total mineral volume, but this increase is insignificant when compared to the total volume available (Fig. 7b). Secondary minerals are the same as those given by all the previous modelings.

\section{Precipitation kinetics versus diffusion}

The existence of a threshold water/rock ratio indicates that the fractures of average aperture are never blocked, whereas the pores are potentially blocked. In this approach, the diffusion was not accounted for. Effective diffusion coefficients have been measured in fresh basalts, indicating that a non-negligible proportion of pores are necessarily connected, or were connected at the early stage of the life of the hydrothermal system. Higher effective diffusion coefficients result in more advanced diffusion fronts. But, if the precipitation kinetics of secondary minerals is fast enough to consider a water/rock ratio of 0.4 (i.e., the threshold water/rock ratio calculated in this section) or less, the alteration is blocked because of mineral volume changes or severely decreased if the diffusion can continue through the secondary minerals. An increase of effective diffusion coefficient of water molecules in fresh basalt from $5.05^{\circ} 10^{-11}$ to $1.19^{\circ} 10^{-10} \mathrm{~m}^{2} / \mathrm{s}$ was measured as temperature increases from 5 to $50{ }^{\circ} \mathrm{C}$, implying an activation energy of $12.3 \mathrm{~kJ} / \mathrm{mol}$ (Simonyan et al. 2012). By using Equation 6, it can be calculated that in 10,000 years, the diffusion front would propagate $6 \mathrm{~m}$ at $50{ }^{\circ} \mathrm{C}$, and $15 \mathrm{~m}$ at $250{ }^{\circ} \mathrm{C}$. We have no clear idea about the thickness of the alteration zone around the fractures; neither if there is a sharp boundary or a progressive transition, but such a diffusion length is in contradiction with the fact that lava flows are rather fresh. In addition, it is worth to note that the age of the fresh mid-ocean ridge basalt mentioned above was estimated at 8.64 Ma (Simonyan et al. 2012). The authors did not provide any information about the temperature, but it is likely that some hydrothermal circulation occurred in such systems. There is a competition between diffusion and secondary mineral precipitation kinetics. The effect of the precipitation kinetics seems to be greater than the effect of the initial diffusion. The diffusion coefficient in unaltered basalts decreases during the alteration, because the mineral volume increase reduces the diameter of the pores. In this way, the bulk basalt becomes resistant from further alteration.

\section{The case of non-connected pores}

The observation of pores that are partially or completely filled with secondary minerals in otherwise unaltered rock raises the question of pore connectivity and how these minerals were formed, i.e., by slow equilibration with the basaltic rock in a closed pore or by hydrothermal alteration due to mass transport in a connected pore space. The possible clogging of narrower pores and fractures (as discussed before) implies that a majority of pores and vesicles are isolated from the water circulation. The calculations 
in the "The complete alteration of hyaloclastites" section were based on the assumption that water can freely circulate in the pore space. The alteration in isolated, nonconnected pores or vesicles (i.e., closed system) was simulated with an additional set of model calculations (Fig. 10). Unlike the calculations in the "The complete alteration of hyaloclastites" section, these ones started with a given amount of water $\left(1 \mathrm{dm}^{3}\right)$ and a relatively small amount of basalt. After equilibration of the system, more basalt was added, thus the system was successively equilibrated with more and more basalt. Figure 10 presents the simulation results for pure water without gases. We conducted simulations for various initial water compositions and found that the evolution of the system shows no significant dependency on the initial water composition or gas content.

Unlike for the cases with water circulation (Figs. 2 and 7), the initial relatively small amount of water is never exchanged, which limits the influence of its initial composition on large amounts of basalt. We found for the isolated pores that, independent from temperature, the volume of secondary minerals is nearly equal to the total volume available in the system. This finding is in agreement with the field observation that the pore spaces of the vesicles are partially or totally filled with secondary minerals (Weisenberger and Selbekk 2009). The calculated mineralogy for isolated pores does not substantially differ from the calculated mineralogy of the connected pore space. The most significant difference concerns the occurrence of the following sequence of zeolites in the model described in the literature (e.g., Gudmundsson and Arnorsson 2005): low-temperature zeolites up to $100{ }^{\circ} \mathrm{C}$, laumontite from 100 to $200{ }^{\circ} \mathrm{C}$, and wairakite above $200^{\circ} \mathrm{C}$. The calculations for the connected pore space did not predict the precipitation of laumontite and wairakite. Therefore, it might be possible that the presence of those two phases is related to the occurrence of isolated pores or vesicles.

\section{A simplified conceptual model}

The results obtained in this study allow us to propose a simplified conceptual model of an Icelandic hydrothermal system (Fig. 11). The model is partial because we did not consider the highest temperature zones. We assume that the water circulation is mainly due to convection. Rainwater or seawater penetrates into the system, and will be progressively heated up, because the temperature increases with the depth. In lava flows, the water circulates along the fractures (vertical permeability) and, to small extent, can penetrate perpendicularly to the fracture flow into the basalt, via diffusive transport. But the low fluid/rock ratio in the pores adjacent to the fractures makes them completely clogged during the transformation of primary minerals into secondary minerals. The water can no longer diffuse through the basalt pores, and the basalt becomes "protected". This potential pore clogging and the existence of a threshold pore/fracture aperture is in accord with the field observation that basalt flows are in most cases rather fresh, and that secondary minerals are found in and around the fractures, and at the interface with the hyaloclastites. The high permeability and porosity of hyaloclastite formations makes the water circulation easier. The water circulation may have a horizontal component because hyaloclastite layers are surrounded by basalt flow layers that are less permeable. The transformation of glass into secondary minerals does not significantly change the porosity, which allows the alteration to progress. The complete 

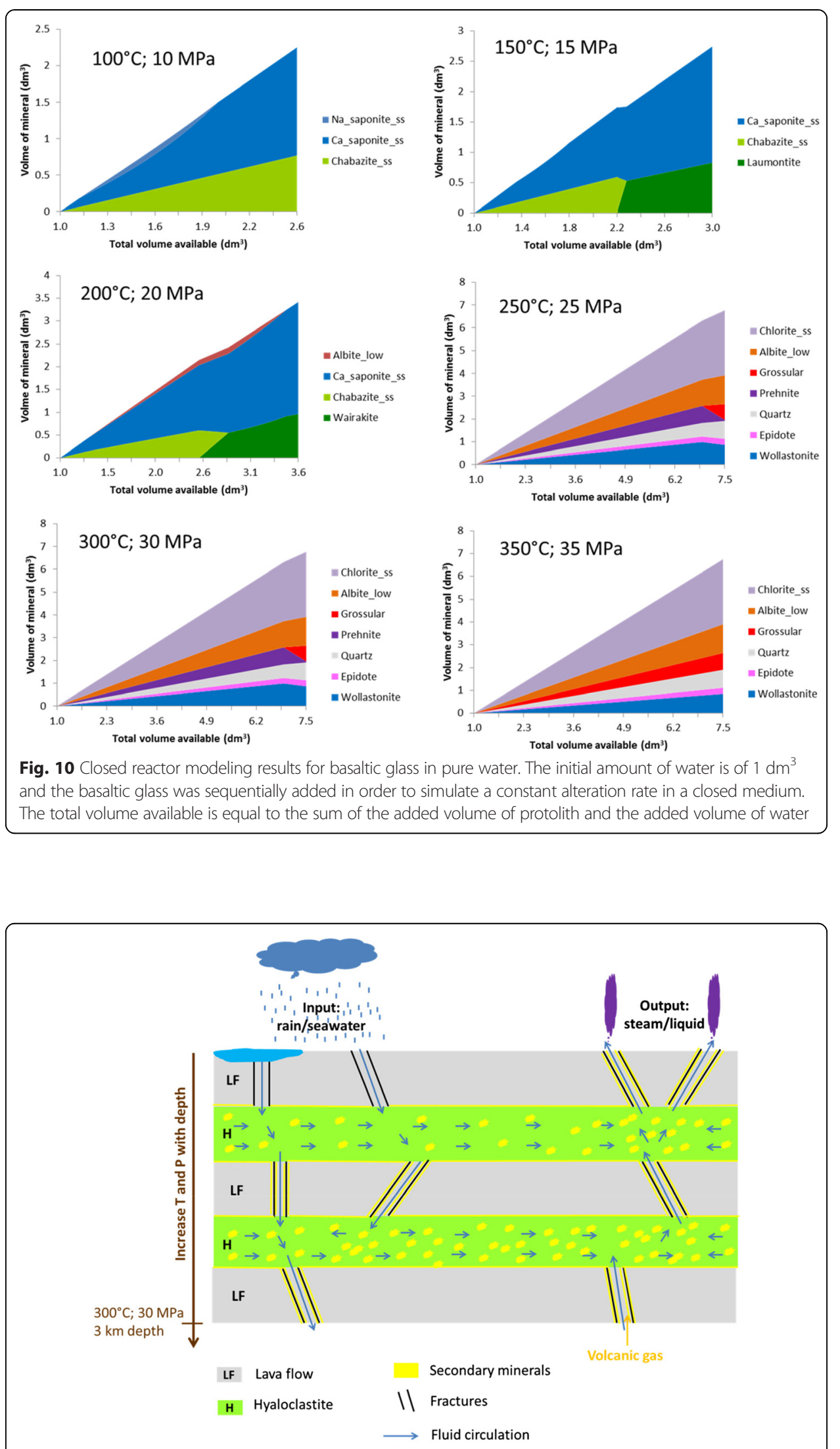

Fig. 11 Conceptual picture of water flow in the hydrothermal system 
alteration of small glassy fragments is rather fast, from a few days to a few hours, due to a low grain size, high surface roughness, and high temperature.

\section{Conclusions}

Field observations show that hyaloclastites are completely altered (i.e., all the protolith had been transformed into secondary minerals), and compact basalts exhibit a wide range of alteration stages (i.e., from not altered to completely altered). In this study, we explore possible reasons that can explain this observation. The initial water/rock ratio has been found to be more important for the evolution of the system than water composition or gas content. The water/rock ratio depends on the porosity and its connectivity (or on the size of a considered pore or fracture), and on the amount of rocks that can react during a given period of time. By considering that the initial pore space is completely filled with water, the lower is the initial water/rock ratio, the more the porosity (or pore or fracture size) decreases during the alteration. In more extreme cases, no connected porosity remains; the water can therefore no longer circulate: the system is impermeable.

The complete alteration of hyaloclastites is possible because of high initial water/ rock ratio which is due to high initial connected porosity and high reactivity of small glass grains. Even if all the initial amount of protolith reacts with water, the available porosity does not noticeably change; the alteration can consequently proceed. This process is fast (from a few hours to a few years) compared to the lifetime of a hydrothermal system (hundreds to thousands years). It is due to the high specific surface area of glassy fragments, as well as to elevated temperatures. This study highlights the fact that in any water-rock interaction study, consideration of dissolution or precipitation kinetics requires a good knowledge of the morphology of the minerals. The role of the specific surface area appears to be much more important than that of the kinetic rate constant.

In lava flows, the water mainly circulates in the fractures. The average size of fractures corresponds to a water/rock ratio that is high enough not to produce any significant porosity change during the alteration, whatever the advancement of the reaction. The fluid flow in the fractures is therefore not affected by precipitation. There is a diffusive exchange of solutes across the fracture walls between the water in the fracture and the pore water of the adjacent rock matrix. The water/rock ratio in the pores close to the fracture walls is so low that on the long term, they become completely filled with secondary minerals. The pore connectivity is thus obstructed, preserving the rest of the basalt from subsequent alteration. Such clogging is only possible under the condition that the precipitation kinetics of secondary minerals is fast enough. The extent of the alteration rim around the fracture appears to be determined by the competition between the precipitation kinetics of secondary minerals and the diffusive transport of solutes in the pore network. Future field observations will provide more data about the extent of alteration rims and also about the fracture size distribution in lava flows. This information is important for the parameterization of a more detailed geochemical reactive transport model that will describe the system evolution by simultaneously accounting for precipitation and dissolution kinetics (i.e., reaction rates and reactive surface areas), diffusion in pores, flow in pores and fractures, as well as heat conductivity changes of the rocks with alteration. 


\section{Competing interests}

The authors declare that they have no competing interests.

\section{Authors' contributions}

All the authors contributed to the literature search, the interpretation of modeling results and the elaboration of the conceptual model. BT did the kinetic model for basaltic glass dissolution, the geochemical reaction path setup and the calculations. All the authors read, enhanced and approved the final manuscript.

\section{Acknowledgements}

The financial support was provided by the Swiss National Science Foundation under the grant number CRSII2_141843/ 1 (Sinergia COTHERM). We also acknowledge the editorial board of Geothermal Energy for giving us the opportunity to present our work as an open issue, and two anonymous reviewers for their suggestions which helped to improve the quality and the readability of this paper.

Received: 11 March 2015 Accepted: 20 May 2015

Published online: 23 June 2015

\section{References}

Advocat T, Jollivet P, Crovisier JL, del Nero M (2001) Long-term alteration mechanisms in water for SON68 radioactive borosilicate glass. J Nucl Mater 298:55-62

Alfredsson HA, Hardarsson BS, Franzson H, Gislason SR (2008) CO2 sequestration in basaltic rock at the Hellisheidi site in SW Iceland: stratigraphy and chemical composition of the rocks at the injection site. Mineral Mag 72:1-5

Alfredsson HA, Oelkers EH, Hardarsson BS, Franzson H, Gunnlaugsson E, Gislason SR (2013) The geology and water chemistry of the Hellisheidi, SW-Iceland carbon storage site. Int J Greenh Gas Con 12:399-418

Altaner SP, Ylagan RF, Savin SM, Aronson JL, Belkin HE, Pozzuoli A (2003) Geothermometry, geochronology, and mass transfer associated with hydrothermal alteration of a rhyolitic hyaloclastite from Ponza Island, Italy. Geochim Cosmochim Acta 67:275-288

Aradottir ESP, Sonnenthal EL, Björnsson G, Jonsson H (2012) Multidimensional reactive transport modeling of $\mathrm{CO}_{2}$ mineral sequestration in basalts at the Hellisheidi geothermal field, Iceland. Int J Greenh Gas Con 9:24-40

Aradottir ESP, Sigfússon B, Sonnenthal EL, Björnsson G, Jónsson H (2013) Dynamics of basaltic glass dissolution-capturing microscopic effects in continuum scale models. Geochim Cosmochim Acta 121:311-327

Arnorsson S (1975) Application of silica geothermomether in low-temperature hydrothermal areas in Iceland. Am J Sci 275(7):763-784

Arnorsson S (1995) Geothermal systems in Iceland: structure and conceptual models-I. High-temperature areas. Geothermics 24(5/6):561-602

Arnorsson S, Gunnlaugsson E, Svavarsson H (1983) The chemistry of geothermal waters in Iceland.2. Mineral equilibria and independent variables controlling water compositions. Geochim Cosmochim Acta 47(3):547-566

Banik TJ, Wallace PJ, Höskuldsson A, Miller CF, Bacon CR, Furbish DJ (2014) Magma-ice-sediment interactions and the origin of lava/hyaloclastite sequences in the Sida formation, South Iceland. Bull Volcanol 76(785):1-19

Barfod DN, Fitton JG (2014) Pleistocene volcanism on São Tomé, Gulf of Guinea, West Africa. Quat Geochronol 21:77-89

Berner RA (2013) From black mud to Earth System science: a scientific autobiography. Am J Sci 313:1-60

Bourcier WL, Peiffer DW, Knauss KG, McKeegan, KD, Smith DK (1990) A kinetic model for borosilicate glass dissolution based on the dissolution affinity of a surface alteration layer. Scientific Basis for Nuclear Waste Management XIII (76):209-2016

Catalano JG (2013) Thermodynamic and mass balance constraints on iron-bearing phyllosilicates formation and alteration pathways on early Mars. J Geophys Res: Planets 118:2124-2136

Claridge GC, Campbell IB (2008) Zeolites in Antarctic soils: examples from Coombs hills and marble point. Geoderma 144:66-72

Committee on Fracture Characterization and Fluid Flow, National Research Council (1996) Rock Fractures and Fluid Flow: Contemporary Understanding and Applications. The National Academies Press, National research Council, Washington DC, USA.

Crovisier JL, Advocat T, Dussossoy JL (2003) Nature and role of natural alteration gels formed on the surface of ancient volcanic glasses (Natural analogs of waste containment glasses). J Nucl Mater 321:91-109

Curti E (1999) Coprecipitation of radionuclides with calcite: estimation of partition coefficients based on a review of laboratory investigations and geochemical data. Appl Geochem 14:433-445

Dessert C, Dupré B, Gaillardet J, François LM, Allègre CJ (2003) Basalt weathering laws and the impact of basalt weathering on the global carbon cycle. Chem Geol 202(3-4):257-273

Ehlmann BL, Bish DL, Ruff SW, Mustard JF (2012) Mineralogy and chemistry of altered Icelandic basalts: Application to clay mineral detection and understanding aqueous environments on Mars. J Geophys Res 117: 1-27

Ferrage E, Lanson B, Michot LJ, Robert $J L$ (2010) Hydration properties and interlayer organization of water and ions in synthetic Na-smectite with tetrahedral layer charge. Part 1. Results from X-ray diffraction profile modeling. J Phys Chem C 114(10):4515-4526

Flury M, Gimmi T (2002) Solute diffusion. Methods and Soil Analysis, Part 4, Physical Methods: 1323-1351. Edited by Dane JH and Topp GC, Soil Science Society of America, Madison WI

Franzson H, Gudlaugsson SP, Fridleifsson GO (2001) Petrophysical properties of Icelandic rocks. Proceedings of the 6th Nordic Symposium on Petrophysics, Tronheim, Norway. In: Knut Backe \& Ton Loermans (ed), The Norwegian University of Science and Technology. Trondheim, Norway

Franzson H, Zierenber R, Schiffman P (2008) Chemical transport in geothermal systems in Iceland. Evidence from hydrothermal alteration. J Volcanol Geotherm Res 173:217-229 
Franzson H, Gudfinnsson GH, Helgadóttir HM, Frolova J (2010) Porosity, density and chemical composition relationships in altered Icelandic hyaloclastites. In: Birkle \& Torres-Alvarado (ed), Water-Rock Interaction. London: Taylor \& Francis Group; 199-202

Franzson H, Gudfinnsson GH, Frolova J, Helgadóttir HM, Pauly B, Mortensen AK, Jakobsson SP (2011) Icelandic Hyaloclastite Tuffs, Petrophysical Properties, Alteration and Geochemical Mobility. Report prepared for National Energy Authority and Reykjavík Energy. Iceland: ISOR, Reykjavik; ÍSOR-2011/064

Freedman AJE, Bird DK, Arnorsson S, Fridriksson T, Elders WA, Fridleifsson GO (2009) Hydrothermal minerals record $\mathrm{CO}(2)$ partial pressures in the Reykjanes geothermal system, Iceland. Am J Sci 309(9):788-833

Fridleifsson GO, Elders WA (2005) The Iceland deep drilling project: a search for deep unconventional geothermal resources. Geothermics 34(3):269-285

Fridriksson T, Neuhoff PS, Arnórsson S, Bird DK (2001) Geological constraints on the thermodynamic properties of the stilbite—stellerite solid solution in low-grade metabasalts. Geochim Cosmochim Acta 65(21):3993-4008

Frolova J, Ladygin V, Franzson H, Sigurdsson O, Stefánsson V, Shustrov V (2005) Petrophysical properties of fresh to mildly altered hyaloclastite tuffs. Proceedings of World Geothermal Congress 2005, Antalya, Turkey, pp 24-29

Frugier P, Gin S, Minet Y, Chave T, Bonin B, Godon N, Lartique JE, Jollivet P, Ayral A, De Windt L, Santarini G (2008) SON68 nuclear glass dissolution kinetics: current state of knowledge and basis of the new GRAAL model. J Nucl Mater 380:8-21

Gaboreau S, Prêt D, Tinseau E, Claret F, Pellegrini D, Stammose D (2011) 15 years of in situ cement-argillite interaction from tournemire URL: characterisation of the multi-scale spatial heterogeneities of pore space evolution. Appl Geochem 26(12):2159-2171

Gin S, Ribet I, Couillard M (2001) Role and properties of the gel formed during nuclear glass alteration: importance of gel formation conditions. J Nucl Mater 298:1-10

Gislason SR, Oelkers EH (2003) Mechanism, rates, and consequences of basaltic glass dissolution: II. An experimental study of the dissolution rates of basaltic glass as a function of $\mathrm{pH}$ and temperature. Geochim Cosmochim Acta 20:3817-3832

Gislason SR, Wolff-Boenisch D, Stefansson A, Oelkers EH, Gunnlaugsson E, Sigurdardottir H, Sigfusson B, Broecker WS, Matter JM, Stute M, Axelsson G, Fridriksson T (2010) Mineral sequestration of carbon dioxide in basalt: a preinjection overview of the CarbFix project. Int J Greenh Gas Con 4(3):537-545

Grambow B, Jercinovic MJ, Ewing RC, Byers CD (1986) Weathered basalt glass: a natural analogue for the effects of reaction progress on nuclear waste glass alteration. Scientific Basis for Nucl Waste Mgt IX 50:363-272

Griffith LL, Shock EL (1997) Hydrothermal hydration of Martian crust: Illustration via geochemical model calculations. J Geophys Res 102:9135-9143

Gronvold F (1976) Heat capacities in critical regions. Plenary Lectures Presented at the Fourth International Conference on Chemical Thermodynamics Université des Sciences et Techniques de Languedoc, Montpellier, France 26-30 August 1975. Chemical Thermodynamics, edited by J. Rouquerol and R. Sabbah, Elsevier.

Gudmundsson BT, Arnorsson S (2002) Geochemical monitoring of the Krafla and Namafjall geothermal areas, N-Iceland. Geothermics 31:195-243

Gudmundsson BT, Arnorsson S (2005) Secondary mineral-fluid equilibria in the Krafla and Namafjall geothermal systems, Iceland. Appl Geochem 20(9):1607-1625

Gunnlaugsson AS (1982) The chemistry of iron in geothermal systems in Iceland. J Volcanol Geotherm Res 14(3-4):281-299

Gustavson JE (2006) Analysis of porosity evolution during low temperature metamorphism of basaltic lava and implications for fluid flow. University of Florida, Master thesis

Gysi AP, Stefansson A (2011) $\mathrm{CO}_{2}$-water-basalt interaction. Numerical simulation of low temperature $\mathrm{CO}_{2}$ sequestration into basalts. Geochim Cosmochim Acta 75:4728-4751

Gysi AP, Stefansson A (2012a) Mineralogical aspects of CO2 sequestration during hydrothermal basalt alteration-an experimental study at 75 to $250^{\circ} \mathrm{C}$ and elevated pCO(2). Chem Geol 306:146-159

Gysi AP, Stefansson A (2012b) Experiments and geochemical modeling of CO2 sequestration during hydrothermal basalt alteration. Chem Geol 306:10-28

Harris KR, Woolf LA (1980) Pressure and temperature dependence of the self diffusion coefficient of water and oxygen-18 water. J.C.S. Faraday 1 76:377-385

Hellevang H, Dypvik H, Kalleson E, Pittarello L, Koeberl C (2013) Can alteration experiments on impact melts from El'gygytgyn and volcanic glasses shed new light on the formation of the Martian surface? Meteorit Planet Sci 48:1287-1295

Holland TGB, Powell R (1998) An internally-consistent thermodynamic dataset for phases of petrological interest. J Metamorphic Geology 16:309-344

Honnorez J (2003) Hydrothermal alteration vs. ocean-floor metamorphism. A comparison between two case histories: the TAG hydrothermal mound (Mid-Atlantic Ridge) vs. DSDP/ODP Hole 504B (Equatorial East Pacific). Comptes Rendus Geoscience 335(10-11):781-824

Hovius N, Lea-Cox A, Turowski JM (2008) Recent volcano-ice interaction and outburst flooding in a Mars polar cap re-entrant. Icarus 197(1):24-38

Hreggvisdottir H (1978) The greenschist to amphibolite facies transition in the Nesjavellir hydrothermal system. Stanford University, CA, M.Sc. thesis

Jarosch A, Gudmundsson MT, Högnadottir T, Axelsson G (2008) Progressive cooling of the hyaloclastite ridge at Gjalp, Iceland, 1996-2005. J Volcanol Geotherm Res 170(3-4):218-229

Kaasalainen H, Stefansson A (2011) Sulfur speciation in natural hydrothermal waters, Iceland. Geochim Cosmochim Acta 75:2777-2791

Kaasalainen H, Stefansson A (2012) The chemistry of trace elements in surface geothermal waters and steam, Iceland. Chem Geol 330(331):60-85

Kanayama K, Umino S, Ishizuka O (2014) Shallow submarine volcano group in the early stage of island arc development: geology and petrology of small islands south off Hahajima main island, the Ogasawara Islands. J Asian Earth Sci 85:1-25 
Karmous MS, Ben Rhaiem H, Robert JL, Lanson B, Ben Haj Amara A (2009) Charge location effect on the hydration properties of synthetic saponite and hectorite saturated by $\mathrm{Na}^{+}, \mathrm{Ca}^{2+}$ cations: XRD investigation. App Clay Sci 46:43-50

Kristmannsdottir H (1979) Alteration of basaltic rock by hydrothermal activity at 100-300 C. In: International clay conference 1978 (edited by Mortland MM and farmer VC). Elsevier, Amsterdam, pp 359-367

Kulik DA, Vinograd VL, Paulsen N, Winkler B (2010) (Ca, Sr)CO3 aqueous-solid solution systems: from atomistic simulations to thermodynamic modelling. Physics and Chemistry of the Earth 35:217-232

Kulik DA, Wagner T, Dmytrieva SV, Kosakowski G, Hingerl FF, Chudnenko KV, Berner U (2013) GEM-Selektor geochemical modeling package: revised algorithm and GEMS3K numerical kernel for coupled simulation codes. Computat Geosci 17:1-24, http://gems.web.psi.ch

Larsson D, Grönvold K, Oskarsson N, Gunnlaugsson E (2002) Hydrothermal alteration of plagioclase and growth of secondary feldspar in the Hengill Volcanic Centre, SW Iceland. J Volcanol Geotherm Res 114(3-4):275-290

Lonker SW, Franzson H, Kristmannsdottir H (1993) Mineral-fluid interactions in the Reykjanes and Svartsengi geothermal systems, Iceland. Am J Sci 293(7):605-670

MacQuarrie KTB, Mayer KU (2005) Reactive transport modeling in fractured rock. A state-of-the-science review. Earth-Sci Rev 72:189-227

Marks N, Schiffman P, Zierenberg RA, Hj F, Fridleifsson GO (2010) Hydrothermal alteration in the Reykjanes geothermal system: Insights from Iceland deep drilling program well RN-17. J Volcanol Geotherm Res 189(1-2):172-190

Markusson SH, Stefansson A (2011) Geothermal surface alteration of basalts, Krysuvik Iceland-alteration mineralogy, water chemistry and the effects of acid supply on the alteration process. J Volcanol Geotherm Res 206(1-2):46-59

Matter JM, Broecker WS, Stute M, Gislason SR, Oelkers EH, Stefansson A, Wolff-Boenisch D, Gunnlaugsson E, Axelsson G, Björnsson G (2009) Permanent carbon dioxide storage into basalt: the CarbFix pilot project, Iceland. Energy Procedia 1(1):3641-3646

Michot LJ, Bihannic I, Pelletier M, Rinnert E, Robert JL (2005) Hydration and swelling of synthetic Na-saponites: influence of layer charge. Am Mineral 90:166-172

Miyashiro A (1975) Metamorphism and Metamorphic belts. London: George Allen \& Unwin Ltd.; 1975

Moore LN, Mueller WU, Daigneault R (2012) In situ hydroclastic fragmentation of subaqueous ponded lavas; New Senator caldera, Abitibi greenstone belt, Quebec, Canada. Precambrian Res 214-215:44-59

Mortensen AK, Egilson P, Gautason B, Arnadottir S, Gudmundsson A (2014) Stratigraphy, alteration mineralogy, permeability and temperature conditions of well IDDP-1, Krafla, NE-Iceland. Geothermics 49:31-41

Motelib AA, Khalaf EA, Al-Marzouki H (2014) Growth, destruction and facies architecture of effusive and explosive volcanics in the Miocene Shama basin, southwest of Saudi Arabia: subaqueous-subaerial volcanism in a lacustrine setting. J Volcanol Geotherm Res 277:51-76

Navarre-Sitchler A, Steefel Cl, Sak PB, Brantley SL (2011) A reactive-transport model for weathering rind formation on basalt. Geochim Cosmochim Acta 75(23):7644-7667

Navarre-Sitchler AK, Cole DR, Rother G, Jin L, Buss HL, Brantley SL (2013) Porosity and surface area evolution during weathering of two igneous rocks. Geochim Cosmochim Acta 109:400-413

Navarre-Sitchler A, Steefel Cl, Yang L, Tomutsa L, Brantley SL (2009) Evolution of porosity and diffusivity associated with chemical weathering of a basalt clast. J Geophys Res: Earth Surf (2003-2012), 114(F2): 1-19

Neuhoff P (2000) Thermodynamic properties of parageneses of rock-forming zeolites. Ph.D. thesis, Stanford University, Stanford, Calif

Neuhoff PS, Fridriksson T, Arnorsson S, Bird DK (1999) Porosity evolution and mineral paragenesis during low-grade metamorphism of basaltic lavas at Teigarhorn, eastern Iceland. Am J Sci 299:467-501

Pham VTH, Lub P, Aagaard P, Zhu C, Hellevang H (2011) On the potential of CO2-water-rock interactions for CO2 storage using a modified kinetic model. Int J Greenh Gas Con 5(4):1002-1015

Pitty AF, Alexander WR (2014) A natural analogue study of cement buffered, hyperalkaline groundwaters and their interaction with a repository host rock IV : an examination of the Khushaym Matruk (central Jordan ) and Maqarin (norhtern Jordan) sites. Technical Report BG-TR-11-02 Vol. 2. Switzerland: Bedrock Geosciences, Auenstein

Rebiscoul D, Van der Lee A, Rieutord F, Né F, Spalla O, El-Mansouri A, Frugier P, Ayral A, Gin S (2004) Morphological evolution of alteration layers formed during nuclear glass alteration: new evidence of a gel as a diffusive barrier. J Nucl Mater 326:9-18

Rinnert E, Carteret C, Humbert B, Fragneto-Cusani G, Ramsay JDF, Delville A, Robert JL, Bihannic I, Pelletier M, Michot LJ (2005) Hydration of a synthetic clay with tetrahedral charges: a multidisciplinary experimental and numerical study. J Phys Chem B 109(49):23745-23759

Saar MO, Manga M (1999) Permeability-porosity relationship in vesicular basalts. Geophys Res Lett 26:111-114

Scanlon KE, Head JW, Wilson L, Marchant DR (2014) Volcano-ice interactions in the Arsia Mons tropical mountain glacier deposits. Icarus 237(15):315-339

Schiffman P, Fridleifsson GO (1991) The smectite chlorite transition in drillhole NJ-15, Nesjavellir geothermal field, Iceland - XRD, BSE and Electron-microscope investigations. Journal of Metamorphic Geology 9(6):679-696

Schleicher AM, Hofmann H, van der Pluijm BA (2013) Constraining clay hydration state and its role in active fault systems. Geochem Geophys Geosyst 14(4):1039-1052

Schopka HH, Gudmundsson MT, Tuffen H (2006) The formation of Helgafell, southwest Iceland, a monogenetic subglacial hyaloclastite ridge: Sedimentology, hydrology and volcano-ice interaction. J Volcanol Geotherm Res 152:359-377

Scott S, Gunnarsson I, Arnorsson S, Stefansson A (2014) Gas chemistry, boiling and phase segregation in a geothermal system, Hellisheidi, Iceland. Geochim Cosmochim Acta 124:170-189

Shao H, Kosakowski G, Berner U, Kulik DA, Mäder U, Kolditz O (2013) Reactive transport modeling of the clogging process at Maqarin natural analogue site. Phys Chem Earth, parts A/B/C 64:21-31

Shibuya T, Tahata M, Ueno Y, Komiya T, Takai K, Yoshida N, Maruyama S, Russell MJ (2013) Decrease of seawater CO2 concentration in the Late Archean: an implication from $2.6 \mathrm{Ga}$ seafloor hydrothermal alteration. Precambrian Res 236:59-64 
Shock EL, Sassani DC, Willis M, Sverjensky DA (1997) Inorganic species in geologic fluids: correlations among standard molal thermodynamic properties of aqueous ions and hydroxide complexes. Geochim Cosmochim Acta 61:907-950

Sigurdsson H (1970) The petrology and chemistry of the Setberg volcanic region and of the intermediate and acid rocks of Iceland. Durham, UK: Ph.D. thesis, Durham University

Sigurdsson O, Stefansson V (2002) Porosity structure of Icelandic basalt. Proc Estonian Acad Sci Geol 51:33-46

Simonyan AV, Dultz S, Behrens H (2012) Diffusive transport of water in porous fresh to altered mid-ocean ridge basalts. Chem Geol 306-307:63-77

Steefel Cl, Lichtner PC (1998) Multicomponent reactive transport in discrete fractures: II: Infiltration of hyperalkaline groundwater at Maqarin, Jordan, a natural analogue site. J Hydr 209: 200-224.

Stefansson A, Arnorsson S (2002) Gas pressures and redox reactions in geothermal fluids in Iceland. Chem Geol 190(1-4):251-271

Stefansson A, Arnorsson S, Gunnarsson I, Kaasalainen H, Gunnlaugsson E (2011) The geochemistry and sequestration of H2S into the geothermal system at Hellisheidi, Iceland. J Volcanol Geotherm Res 202:179-188

Steingrimsson B, Gudmundsson A, Sigurdsson O, Gunlaugsson E (1986a) Nesjavellir well NJ-11. National Energy Authority Report OS-86025/JHD-0.5, in Icelandic

Steingrimsson B, Fridleifsson GO, Sverrisdottir G, Tulinius H, Sigurdsson O, Gunnlaugsson E (1986b) Nesjavellir well NJ-15, Drilling, investigation and production characteristics. National Energy Authority Report OS-96029/JHD-09, in Icelandic

Steinthorsson S, Sveinbjörnsdottir AE (1981) Opaque minerals in geothermal well no.7, Krafla, Northern Iceland. J Volcanol Geotherm Res 10:245-261

Strachan DM, Neeway JJ (2014) Effects of alteration product precipitation on glass dissolution. Appl Geochem 45:144-157

Stryjek R, Vera JH (1986) PRSV2: a cubic equation of state for accurate vapor-liquid equilibria calculations. Can J Chem Eng 64:820-826

Sveinbjörnsdottir AE (1992) Composition of geothermal minerals from saline and dilute fluids - Krafla and Reykjanes, Iceland. Lithos 17:301-315

Techer I, Advocat T, Lancelot J, Liotard JM (2001) Dissolution kinetics of basaltic glasses: control by solution chemistry and protective effect of the alteration film. Chem Geol 176:235-263

Thien BMJ (2014) A simple way to constrain the stoichiometry of secondary smectites upon glass alteration. Appl Geochem 42:45-46

Thien B, Godon N, Hubert F, Angeli F, Gin S, Ayral A (2010) Structural identification of a trioctahedral smectite formed by the aqueous alteration of a nuclear glass. Appl Clay Sci 49(3):135-141

Thien BMJ, Godon N, Ballestero A, Gin S, Ayral A (2012) The dual effect of Mg on the long-term alteration rate of AVM nuclear waste glasses. J Nucl Mater 427:297-310

Thien BMJ, Kulik DA, Curti E (2014) A unified approach to model uptake kinetics of trace elements in complex aqueous - solid solution systems. Appl Geochem 41:135-150

Tomasson J, Kristman H (1972) High-temperature alteration minerals and thermal brines, Reykjanes, Iceland. Contrib Mineral Petr 36(2):123-137

Vidal O, Dubacq B (2009) Thermodynamic modelling of clay dehydration, stability and compositional evolution with temperature, pressure and $\mathrm{H}_{2} \mathrm{O}$ activity. Geochim Cosmochim Acta 73(21):6544-6564

Vieillard P (2000) A new method for the prediction of Gibbs free energies of formation of hydrated clay minerals based on the electronegativity scale. Clays and Clay Minerals 48(4):459-473

Vieillard P (2007) THERMOCHIMIE- estimation des enthalpies de formation des phyllosilicates anhydres. Hydrasa-INSU FRE3114 N²007-03, 20.2007, Report, in French

Wagner T, Kulik DA, Hingerl FF, Dmytrieva SV (2012) GEM-Selektor geochemical modeling package: TSolMod library and data interface for multicomponent phase models. Can Mineral 50:1173-1195

Walker GPL (1960) Zeolite zones and dike distribution in relation to the structure of the basalts of eastern Iceland. J Geol 68(5):515-528

Watton TJ, Jerram DA, Thordarson T, Davies RJ (2013) Theree-dimensional facies variations in hyaloclastite deposits. J Volcanol Geotherm Res 250:19-33

Weisenberger T, Selbekk RS (2009) Multi-stage zeolite facies mineralization in the Hvalfjördur area, Iceland. Int J Sci 98:985-999

Wolff-Boenisch D, Gislason SR, Oelkers EH, Putnis CV (2004) The dissolution rates of nuclear glasses as a function of their composition at pH 4 and 10.6, and temperatures from 25 to $74^{\circ} \mathrm{C}$. Geochim Cosmochim Acta 68(23):4843-4858

Wolff-Boenisch D, Gislason SR, Oelkers EH (2006) The effect of crystallinity on dissolution rates and CO2 consumption capacity of silicates. Geochim Cosmochim Acta 70(4):858-870

Zezin DY, Migdisov AA, Williams-Jones AE (2011) PVTx properties of $\mathrm{H}_{2} \mathrm{O}-\mathrm{H}_{2} \mathrm{~S}$ fluid mixtures at elevated temperature and pressure based on new experimental data. Geochim Cosmochim Acta 75:5483-5495

Zierenberg RA, Schiffman P, Jonasson IR, Tosdal R, Pickthorn W, McClain J (1995) Alteration of basalt hyaloclastite at the off-axis Sea Cliff hydrothermal field, Gorda Ridge. Chem Geol 126:77-99 